\title{
Cowpea aphid-borne mosaic virus (CABMV) in Passiflora by qPCR analysis reveals asymptomatic plants with viruses and new species with immunity
}

\section{Zanon Santana Gonçalves}

Universidade de Santa Cruz

Onildo Nunes de Jesus ( $\boldsymbol{\nabla}$ onildo.nunes@embrapa.br)

EMBRAPA Centro Nacional de Pesquisa de Mandioca e Fruticultura Tropical https://orcid.org/00000003-1506-101X

Lucas Kennedy Silva Lima

Embrapa Mandioca e Fruticultura

Ronan Xavier Corrêa

Universidade Estadual de Santa Cruz

\section{Research Article}

Keywords: Passifloraceae, Potyvirus, Screening, Genetic resistance, Plant immunity, qPCR

Posted Date: February 15th, 2021

DOI: https://doi.org/10.21203/rs.3.rs-234183/v1

License: (c) (i) This work is licensed under a Creative Commons Attribution 4.0 International License. Read Full License 


\section{Abstract}

The passion fruit woodiness disease (Cowpea aphid-borne mosaic virus - CABMV) causes socioeconomic problems for Brazilian passion fruit crop. Understanding the temporal progress of the disease and identifying resistance sources to CABMV are essential steps to develop resistant varieties. The objective of the study was to evaluate temporal progress of passion fruit woodiness disease, identify Passiflora genotypes with CABMV resistance and to detect virus infection in asymptomatic plants by qPCR. The experiment was conducted in a greenhouse using 128 genotypes belonging to 12 species and three hybrids (inter and intraspecific) of Passiflora evaluated in five periods after inoculation. The symptoms severity was quantified from the disease index (DI\%). The CABMV infection in symptomatic plants was confirmed by RT-PCR and in asymptomatic plants by qPCR. Progress rates and disease severity were lower in the species $P$. cincinnata, $P$. gibertii, $P$. miersii e $P$. mucronata compared to $P$. edulis, $P$. alata, Passiflora sp. and hybrids. Of the evaluated genotypes, $20.31 \%$ were resistant, with emphasis on the accessions of $P$. suberosa, P. malacophylla, P. setacea, P. pohlii e P. bahiensis that did not show symptoms of virus. The absence of symptoms does not imply immunity of plants to the virus, as the qPCR analysis confirmed infection by the virus in asymptomatic plants of $P$. cincinnata, $P$. gibertii, $P$. miersii, $P$. mucronata, $P$. setacea, $P$. malacophylla e $P$. suberosa. Even after four inoculations, the virus was not detected by qPCR in the upper leaves in plants of $P$. pohlii and $P$. bahiensis indicating that these species are immune to CABMV.

\section{Introduction}

Brazil stands out as the largest global producer of yellow passion fruit (Passiflora edulis Sims) [1, 2]. In 2018 the production was $602.651 \mathrm{t}$ in an area of 42.731 ha. Despite being the largest worldwide producer, the average productivity of $14.1 \mathrm{tha}^{-1}$ is low [3]. This low yield, in part, is associated with high severity of the passion fruit woodiness disease, attributed to Cowpea aphid-borne mosaic virus - CABMV [4-7].

CABMV (Potyviridae family and Potyvirus genus) has genome consisting of single stranded RNA (ssRNA), responsible for the expression of viral replication protein, accumulation, defense, viral movement and symptoms in infected plants $[8,9]$. The virus acquisition and transmission are performed by aphides vectors (Hemiptera order and Aphididae family) in a non-circulatory and non-persistent way during the proof stunt [10-12]. Plants infected by CABMV present leaves with mosaic, blister or deformations, reduction in the plant size, deformed fruits, hardened and reduced size $[10,13]$.

Viruses is considered the disease with the highest socioeconomic impact for passion fruit cultivation in Brazil, because it reduces the longevity, productivity and fruit quality and there are no totally effective measures in the disease control $[14,15]$. Indeed, there are important results in the adoption of disease management in field conditions, with the elimination of sick plants (roguing) and replacement with healthy plants, modifications in the plant conduction system as a measure of control and dissemination of the disease [16]. However, the implementation of these management strategies requires additional costs in the production, making it unfeasible for many producers that have low technology. 
Despite advances in disease management, the use of resistant cultivars is considered the best strategy, because it does not demand increased production costs with manpower or chemicals $[17,18]$. However, so far there are no yellow passion fruit cultivars ( $P$. edulis Sims) with this attribute [18-20]. On the other hand, several studies indicate that wild passion tree species carry CABMV resistance genes [21-24], and it is an alternative to develop resistant cultivars $[18,25]$.

The evaluation of the Passion Fruit Germplasm Active Bank aiming to identify resistant wild genotypes is considered an indispensable step for the development of CABMV resistant cultivars [24]. However, the evaluation and accuracy in the quantification of viruses symptoms are highly dependent on the methodology used, which has direct relation to the quality of the data generated for subsequent manipulation and analysis [26]. In this pathosystem, the disease phytopathometric indices have been used to quantify the CABMV symptoms in Passiflora species [24, 26-28]. However, inferring the species reaction only with leaf symptoms evaluations has not been sufficient to determine the resistance level, because wild species with greater tolerance may not manifest leaf symptoms and are classified as immune, but the virus may be present in the tissues. In this context, the real time quantitative PCR (qPCR) opens the perspective for quantification of the viral load in plants due to the high sensitivity of the technique $[29,30]$. Despite the relevance, there are few studies that identify the resistance and/or immunity of wild passion fruit species by means of qPCR.

Thus, this study had the following objectives: $I$ ) evaluate the progress of passion fruit woodiness disease symptoms (Cowpea aphid-borne mosaic virus - CABMV) in different Passiflora species, ii) perform screening in Passiflora spp. genotypes for identification of CABMV resistance sources, aiming to select genotypes with high resistance degree for using in interspecific hybridizations, and iii) detect the infection in plants with symptoms through RT-PCR and in asymptomatic plants from the quantitative real-time PCR (qPCR).

\section{Material And Methods}

\section{Location and Plant material}

The research was developed in Embrapa Mandioca e Fruticultura, located in Cruz das Almas, Bahia, Brazil ( $12^{\circ} 40^{\prime} 39^{\prime \prime} \mathrm{S}, 39^{\circ} 06^{\prime} 23^{\prime \prime} \mathrm{O}, 226 \mathrm{~m}$ altitude), with the climate of the transition region Am to Aw type (tropical sub-humid to dry) and annual average air temperature of $23.8^{\circ} \mathrm{C}$. One hundred and twenty eight Passiflora spp. genotypes were evaluated derived from the Passion fruit Germplasm Active Bank of Embrapa Mandioca e Fruticultura (GAB-Passion fruit) belonging to 12 species and three intra and interspecific hybrids, 54 genotypes of Passiflora edulis Sims., 27 interspecific hybrids (six simple hybrids $\left(\mathrm{F}_{1}\right)$ and 21 of the third generation of backcrossing $\left[\mathrm{BC}_{3}-(\right.$ P.edulis $\times$ P.cincinnata $) \times$ P.edulis $\left.)\right]$, six intraspecific hybrids, 21 of P.cincinnata Mast., three of $P$. mucronata Lam., P. gibertii N.E Brown., P. alata Curtis., and $P$. setacea DC., and one of $P$. pohlii Mast., $P$. miersii Mast., $P$. bahiensis Klotzsch., $P$. malacophylla Mast., $P$. suberosa L., Passiflora sp. Other two genotypes were used as control for the susceptibility reaction (P. edulis, CV. BRS Gigante Amarelo) and resistance (P. cincinnata, BGP200) [24] 
during the entire evaluation of the symptoms caused by the passion fruit woodiness disease (Cowpea aphid-borne mosaic virus - CABMV) (Table 1).

Table 1. Relation of genotypes of Passiflora spp. used for the characterization of the reaction to passion fruit woodiness disease (Cowpea aphid-borne mosaic virus - CABMV).

\begin{tabular}{|c|c|c|c|c|c|c|c|}
\hline $\mathrm{N}^{\circ}$ & Code $^{*}$ & Species & State & No & Code $^{*}$ & Species & State \\
\hline 1 & BGP152 & P. sub & SP & 65 & BC3.133 & Inter $\mathrm{H}^{2}$ & BA \\
\hline 2 & BGP170 & P. mal & SP & 66 & BGP449 & P. ed & RJ \\
\hline 3 & BGP434 & P. set & BA & 67 & BC3.491 & Inter $\mathrm{H}^{2}$ & BA \\
\hline 4 & BGP454 & P. poh & BA & 68 & BGP418-S3 & P. ed & BA \\
\hline 5 & BGP477 & P. bah & BA & 69 & BGP344 & P. ed & BA \\
\hline 6 & BGP244 & P. set & BA & 70 & BGP161 & P. ed & BA \\
\hline 7 & BRS Pérola do Cerrado & P. set & DF & 71 & BGP399 & P. ed & BA \\
\hline 8 & BGP421 & P. cin & BA & 72 & BC3Top-DX & Inter $\mathrm{H}^{2}$ & BA \\
\hline 9 & BGP422 & P. cin & BA & 73 & BGP224 & P. ed & BA \\
\hline 10 & BGP279 & P. cin & BA & 74 & BGP475 & P. ed & BA \\
\hline 11 & BGP276 & P. cin & BA & 75 & BC3.584 & Inter $\mathrm{H}^{2}$ & BA \\
\hline 12 & BGP085 & P. gib & MG & 76 & ВСЗТор-51 & Inter $\mathrm{H}^{2}$ & BA \\
\hline 13 & BGP290 & P. cin & BA & 77 & H09-157 & P. ed & RJ \\
\hline 14 & BGP300 & P. cin & BA & 78 & BGP418-S7 & P. ed & BA \\
\hline 15 & BGP243 & P. cin & BA & 79 & ВС3Тор-5 & Inter $\mathrm{H}^{2}$ & BA \\
\hline 16 & BGP478 & P. muc & MG & 80 & BGP175 & P. ed & BA \\
\hline
\end{tabular}

Table 1. Continuation 


\begin{tabular}{|c|c|c|c|c|c|c|c|}
\hline $\mathrm{N}^{0}$ & Código* & Espécie & Estado & $\mathrm{N}^{\circ}$ & Código* & Espécie & Estado \\
\hline 17 & BGP480 & P. cin & BA & 81 & ВСЗТор-18 & Inter $\mathrm{H}^{2}{ }^{2}$ & BA \\
\hline 18 & BGP481 & P. cin & BA & 82 & ОТН-122 & Inter $\mathrm{H}^{1}{ }^{1}$ & BA \\
\hline 19 & BGP414 & P. gib & SP & 83 & BGP326 & P. ed & SP \\
\hline 20 & BGP114 & P. muc & SP & 84 & ВС3438 & Inter $\mathrm{H}^{2}{ }^{2}$ & BA \\
\hline 21 & BGP246 & P. cin & BA & 85 & BGP203 & P. ed & BA \\
\hline 22 & BGP453 & P. mie & RJ & 86 & BGP418 & P. ed & BA \\
\hline 23 & BGP008 & P. gib & SP & 87 & BGP418-S4 & P. ed & BA \\
\hline 24 & BGP349 & P. cin & BA & 88 & ВСЗТор-97 & Inter $\mathrm{H}^{2}{ }^{2}$ & BA \\
\hline 25 & BGP $200^{3}$ & P. cin & SP & 89 & BGP310 & P. ed & BA \\
\hline 26 & BGP268 & P. cin & BA & 90 & BC3.52 & Inter $\mathrm{H}^{2}{ }^{2}$ & BA \\
\hline 27 & ОТН-137 & Inter $\mathrm{H}^{1}{ }^{1}$ & BA & 91 & H09-125-S3 & P. ed & BA \\
\hline 28 & BGP389 & P. cin & BA & 92 & BC3.507 & Inter $\mathrm{H}^{2}{ }^{2}$ & BA \\
\hline 29 & BGP294 & P. cin & BA & 93 & H09-125-S1 & P. ed & BA \\
\hline 30 & BGP297 & P. cin & BA & 94 & BGP347 & P. ed & BA \\
\hline 31 & BGP286 & P. cin & BA & 95 & H09-156 & P. ed & RJ \\
\hline 32 & BGP398 & P. cin & BA & 96 & H09-122-S2 & P. ed & BA \\
\hline 33 & BGP483 & P. cin & MS & 97 & BGP190 & P. ed & SP \\
\hline 34 & BGP479 & P. muc & BA & 98 & BGP338 & P. ed & BA \\
\hline 35 & BGP274 & P. cin & BA & 99 & BGP337 & P. ed & BA \\
\hline 36 & BGP275 & P. cin & BA & 100 & ВСЗТор-58 & Inter $\mathrm{H}^{2}{ }^{2}$ & BA \\
\hline 37 & BGP308 & P. cin & BA & 101 & BGP450 & P. ed & BA \\
\hline 38 & BGP124 & P. ed & BA & 102 & BGP436 & P. ed & BA \\
\hline 39 & BGP225 & P. ed & BA & 103 & ВС3.554 & Inter $\mathrm{H}^{2}{ }^{2}$ & BA \\
\hline 40 & BGP076 & P. ed & BA & 104 & H09-123 & P. ed & BA \\
\hline 41 & BGP338 & P. ed & BA & 105 & BGP235 & P. ala & DF \\
\hline 42 & BGP418-S1 & P. ed & BA & 106 & H09-111 & Intra H. & BA \\
\hline
\end{tabular}




\begin{tabular}{|c|c|c|c|c|c|c|c|}
\hline 43 & BGP445 & P. ed & BA & 107 & H09-122-S1 & P. ed & BA \\
\hline 44 & BGP402 & P. ed & BA & 108 & BGP476 & P. ed & BA \\
\hline 45 & BGP482 & Passiflora sp. & SP & 109 & BGP024 & P. ala & DF \\
\hline 46 & BGP423 & P. ed & BA & 110 & OTH154 & P. ed & BA \\
\hline 47 & BGP418-S6 & P. ed & BA & 111 & BGP429 & P. ed & BA \\
\hline 48 & ВС3Тор-46 & Inter $\mathrm{H}^{2}$ & BA & 112 & BGP214 & P. ed & SP \\
\hline 49 & BGP418-S2 & P. ed & BA & 113 & BGP427 & P. ed & BA \\
\hline 50 & ВС3Тор-94 & Inter $\mathrm{H}^{2}$ & BA & 114 & BGP330 & P. ed & BA \\
\hline 51 & BGP188 & P. ed & SP & 115 & H09-126 & P. ed & RJ \\
\hline 52 & BC3.112 & Inter $\mathrm{H}^{2}$ & BA & 116 & BRS Gigante Amarelo ${ }^{4}$ & Intra $\mathrm{H}$. & BA \\
\hline 53 & BGP093 & P. ed & BA & 117 & ОТН-101 & Inter $\mathrm{H}^{1}{ }^{1}$ & BA \\
\hline 54 & BC3.183 & Inter $\mathrm{H}^{2}{ }^{2}$ & BA & 118 & BGP393 & P. ala & RJ \\
\hline 55 & ВСЗТор-32 & Inter $\mathrm{H}^{2}$ & BA & 119 & ВС3Тор-34 & Inter $\mathrm{H}^{2}$ & BA \\
\hline 56 & BGP424 & P. ed & BA & 120 & ВС3Тор-44 & Inter $\mathrm{H}^{2}{ }^{2}$ & BA \\
\hline 57 & BGP418-S5 & P. ed & BA & 121 & H09-158 & Intra $\mathrm{H}$. & BA \\
\hline 58 & ОТН-138 & Inter $\mathrm{H}^{1}{ }^{1}$ & BA & 122 & ОТН-93 & Inter $\mathrm{H}^{1}{ }^{1}$ & BA \\
\hline 59 & BGP047 & P. ed & SP & 123 & H09-125-S2 & P. ed & BA \\
\hline 60 & ВС3.507 & Inter $\mathrm{H}^{2}$ & BA & 124 & H09-02 & Intra H. & BA \\
\hline 61 & BGP302 & P. ed & BA & 125 & H09-155 & P. ed & BA \\
\hline 62 & OTH-88 & Inter $\mathrm{H}^{1}{ }^{1}$ & BA & 126 & H09-110 & Intra $\mathrm{H}$. & BA \\
\hline 63 & H09-154 & P. ed & BA & 127 & H09-09 & Intra $\mathrm{H}$. & BA \\
\hline 64 & BGP325 & P. ed & DF & 128 & H09-112 & Intra $\mathrm{H}$. & BA \\
\hline
\end{tabular}

${ }^{*}$ Registration of the Passion fruit Germplasm Active Bank of Embrapa Mandioca and Fruticultura. ${ }^{* *} P$. sub $=$ Passiflora suberosa; $P$. mal $=P$. malacophylla; $P$. set $=P$. setacea; $P$. poh $=$ P. pohlii, $P$. bah $=$ P. bahiensis; $P . \operatorname{cin}=P$. cincinnata; $P$. gib $=P$. gibertir; $P$. muc $=P$. mucronata; $P$. mie $=P$. miersii; ${ }^{1}$ Inter $\mathrm{H} .=$ Simple interspecific Hybrid (F1); ${ }^{2}$ Inter $\mathrm{H}_{\text {. }}=$ Interspecific hybrid of the third generation of backcrossing $\left[\mathrm{BC}_{3}-(P\right.$. edulis $\times$ P. cincinnata) $\times$ P. edulis)]; $P$. ed = P. edulis Sims; $P$. ala = P. alata; Intra $\mathrm{H}_{\text {. }}=$ Intraspecific hybrid. BA = Bahia; RJ = Rio de Janeiro; $M G$ = Minas Gerais; $S P$ = São Paulo; $M S$ = Mato Grosso do Sul; DF = Distrito Federal. ${ }^{3,4}$ P. cincinnata genotype (BGP200) and yellow passion fruit cultivar (P. edulis, CV. BRS Gigante 
Amarelo) used as resistance and susceptibility controls during the evaluations of leaf symptoms caused by CABMV.

\section{Biological essay and sampling}

Approximately 80 seeds of each genotype were soaked in $2 \mathrm{~mL}$ of the growth regulator $\mathrm{GA}_{4+7}+\mathrm{N}$ (phenylmethyl) -aminopurine (Promalin ${ }^{\circledR}$ ) at concentration of $400 \mathrm{mg}^{-1} \mathrm{~L}^{-1}$ for 24 hours [31]. After this period, the seeds were sown in 162 cells rigid polypropylene trays $(50 \mathrm{~mL}$ of vol.) filled with coconut fiber mixture (Gold Mix ${ }^{\circledR}$ ) and commercial substrate $\left(\right.$ Vivato $\left.^{\circledR}\right)$ in the ratio of $3: 1$ (v:v) with the addition of $50 \mathrm{~g}$ of slow release fertilizer (Osmocote ${ }^{\circledR}$ ) for each $10 \mathrm{~L}$ of substrate. After emergence (40 days after sowing) the 30 most uniform plants were selected to compose the essay. Subsequently, the plants were transferred to polypropylene tubes $\left(100 \mathrm{~cm}^{3}\right)$ and conditioned in a vegetation house with temperature of $28 \pm 2{ }^{\circ} \mathrm{C}$ and relative humidity $(\mathrm{RU})$ of $75 \pm 5 \%$ during the entire essay.

\section{Inoculations and evaluations of the symptoms induced by CABMV}

The inoculations with CABMV were performed artificially when the plants had at least four expanded leaves, approximately 60 days after the emergence of the seedlings. The CABMV isolate was derived from yellow passion fruit matrices plants ( $P$. edulis Sims) with severe symptoms of the disease maintained in a greenhouse. The mechanical inoculation was performed as described by Gonçalves et al. [24], two inoculations per plant were performed with four days interval between the first and the second (Fig. 1).

The symptoms characterization was performed based on observations on the variation in the intensity of leaf symptoms in each evaluated leaf [24]. For that purpose, the diagram scale was used that varies from 1 (without symptoms) to 4 (severe symptoms) proposed by Novaes and Rezende [32], according to leaf symptoms demonstrated in Fig. 2. The evaluations started 12 days after the first inoculation (DAI) in all plants from the first leaf of the fully developed apex, totaling five leaves per plants. Subsequent evaluations were performed weekly and ended with $40 \mathrm{DAl}$.

\section{Evaluation of CABMV severity and incidence}

The leaf symptoms evaluation data of each plant (grades 1 to 4 ) in the five evaluation times $(12,19,26$, 33 and $40 \mathrm{DAl}$ ) were used to obtain the disease index (DI). The symptoms severity was measured from McKinney [33] disease severity index, considering the following formula: $\mathrm{DI}(\%)=(\mathrm{DS} \times \mathrm{L}) /(\mathrm{TNL} \times \mathrm{HGS})$; where: $D S=$ degree of the determined scale for each leaf; $L=$ number of leaves with each degree of symptoms (grades); TNL = total number of evaluated leaves, $\mathrm{HGS}=$ maximum infection degree (maximum grade). The incidence of the disease in genotypes was evaluated considering the percentage (\%) of plants that presented typical CABMV symptoms.

\section{Reinoculation and evaluation of asymptomatic plants}


After finishing the leaf symptoms evaluations at $40 \mathrm{DAl}$, plants that did not manifest viruses symptoms (asymptomatic) were separated for new inoculations, in order to confirm plant resistance to CABMV (Fig. 3). These asymptomatic plants ( $n=7$ to 25 ) of the 34 genotypes (Table 3 ) were pruned at $15 \mathrm{~cm}$ (Fig. $3 c$ ). After 40 days of pruning (DAP), when plants had at least four leaves, inoculations and leaf symptoms evaluations were performed as described in item 2.3 and 2.4.

\section{Detection of CABMV by qualitative RT-PCR}

\section{Extracting and treatment of total plant RNA}

At 40 DAl, apical leaf tissue samples were collected from symptomatic inoculated plants (S-IP) and asymptomatic (A-IP), symptomatic reinoculated plants (S-RIP) and asymptomatic (A-RIP), and uninoculated plants (NIP - negative controls) of the 12 Passiflora spp. and hybrids (inter and intraspecific). RNA extractions were performed from the pool formation containing five apical leaves (about $0.5 \mathrm{~g}$ ) representative of the five plants of each of the five sets (S-IP, A-IP, S-RIP, A-RIP, and NIP) (Fig. 3a-d), following the protocol of Ferreira et al. [34]. Pellets containing the RNAs were eluted between 40-80 $\mu \mathrm{L}$ with nuclease-free water (Promega $\left.{ }^{\mathrm{Tw}}\right)$. The treatment was performed with $10 \mu \mathrm{L}$ of total RNA $(10 \mu \mathrm{g} . \mu \mathrm{L})$ and $1.5 \mu \mathrm{L}$ of the DNase enzyme (TURBO DNA-free ${ }^{m}$ Kit $-2 \mathrm{U} . \mu \mathrm{L}^{-1}$ ) according to the manufacturer recommendations $\left(\operatorname{Ambion}^{\circledR}\right)$. To evaluate purity via ratio $260 / 280$ and $260 / 230(2.0 \pm 1$ ) as well as to estimate the total RNA concentration were performed three readings of each sample $(1.0 \mathrm{uL})$ in NanoVue ${ }^{\text {tw' }}$ Plus spectrophotometer (GE Healthcare), with the RNA concentration adjusted to approximately 100 ng.uL ${ }^{-1}$.

\section{Obtaining complementary DNA (CDNA) and Polymerase Chain Reaction (PCR)}

The cDNA was synthesized with $3.0 \mu \mathrm{L}$ of total RNA $\left(100 \mathrm{ng}^{-\mu \mathrm{L}^{-1}}\right), 1.0 \mu \mathrm{L}$ of Oligo $\mathrm{d}(\mathrm{T})_{18}$ and random primer, $1.0 \mu \mathrm{L}$ of dNTP $(2.5 \mathrm{mM})$ and $7 \mu \mathrm{L}$ of water, heating at $65^{\circ} \mathrm{C}$ for $5 \mathrm{~min}$. Then we added $4.0 \mu \mathrm{L}$ of buffer, $2.0 \mu \mathrm{L}$ of DTT $(0.1 \mathrm{M}), 1.0 \mu \mathrm{L}$ of RNase out ${ }^{\mathrm{Tt}}$ and $1.0 \mu \mathrm{L}$ of M-MLV (Invitrogen ${ }^{\mathrm{Tw}}, 200 \mathrm{U}^{\mathrm{N}} \mu \mathrm{L}^{-1}$ ), under thermocycling of $37^{\circ} \mathrm{C}$ for $50 \mathrm{~min}$. and inactivation of the enzyme at $70^{\circ} \mathrm{C}$ for $15 \mathrm{~min}$. PCR reactions were performed with specific primers [CABMV/M1MX3726_F (5' GAGACACAAGCCAAAACACAAAATC 3') and CABMV/M1MX5039_R (5' CGTTGCTACAAATTCTGGTATCTCC $3^{\prime}$ )] that amplifies part of the CABMV cylindrical inclusion gene of 1311 pb [35] (Fig. 4).

PCR reactions were performed with $3.0 \mu \mathrm{L}$ of $\mathrm{CDNA}$ (diluted in 1:10), $0.5 \mu \mathrm{L}$ of primer $(10 \mu \mathrm{M})$ and Taq polymerase (5 U. $\mu \mathrm{L}^{-1}-$ Invitrogen ${ }^{\mathrm{TM}}$ ) according to Gonçalves et al. [24]. The amplification program was 95 ${ }^{\circ} \mathrm{C}$ for 3 min., followed by 38 cycles at $94^{\circ} \mathrm{C}$ for 45 sec., $54{ }^{\circ} \mathrm{C}$ for $45 \mathrm{sec}$., $72{ }^{\circ} \mathrm{C}$ for $1: 30$ sec., followed by a final extension of $72{ }^{\circ} \mathrm{C}$ for 4 min. As positive control (PC) was used leaf tissue pool of matrix plants ( $\mathrm{n}$ $=5, P$. edulis) with symptoms of the disease collected at $40 \mathrm{DAl}$, with the CDNA concentration adjusted to $200 \mathrm{ng} . \mathrm{LL}^{-1}$. The PCR products were analyzed by electrophoresis ( 80 volts, $2 \mathrm{~h}: 30 \mathrm{~min}$.) and agarose gel 1\% (Tris-borate and EDTA, pH 8.0), and the amplicons were visualized by Kodak GeoLogic-220 pro photo 
documenter (Carestream). The amplicons size was determined with $5.0 \mu \mathrm{L}$ of Low Mass DNA Ladder of 1 $\mathrm{Kb}$ (Invitrogen $\left.{ }^{\mathrm{t}}\right)$.

Quantitative real-time PCR (Polymerase Chain Reaction - qPCR)

\section{Amplification efficiency of the real-time PCR essay (qPCR)}

For the amplification efficiency essay a standard sample was prepared for using in decimal serial dilutions $\left(10^{\mathrm{n}}\right)$. The total RNA sample was used $\left(100 \mathrm{ng} \cdot \mathrm{\mu L}^{-1}\right)$ of $P$. edulis $40 \mathrm{DAl}$. Then four cDNA syntheses of the same sample were proceeded (2.6.2). In the sequence, PCR reactions of each of the four repetitions (2.6.2) were performed, and analyzed in agarose gel $1 \%$ to verify the formation of unique amplicons. Finally, the four cDNA repetitions were gathered forming a composite sample (pool), quantified (3x) (NanoVue ${ }^{\mathrm{tm}}$ Plus Spectrophotometer) and the concentration fixed to $200 \mathrm{ng}^{\mathrm{\mu l}} \mathrm{L}^{-1}$.

The essay was performed obtaining a curve with five points $\left(10^{10}\right.$ to $\left.10^{6}\right)$ of dilution in series of ten times; $1: 20,1: 200,1: 2000$ and 1:20,000, starting from 200 to $0.02 \mathrm{ng}_{\mathrm{\mu L}} \mathrm{L}^{-1}$. The primer pair used was qCABMV07_For (5' CTGGTAGAGTGCTTCTCAATTTGG 3') and qCABMV07_Rev (5' CTCTCCCTTGATGGCCTCAA 3') designed to amplify part of the CABMV coat protein gene of $121 \mathrm{pb}$ [37] (Fig. 4). The tests were performed by RT-qPCR Sybr ${ }^{\circledR}$ Green reagent in technical triplicates (7500 Fast Real-Time PCR System - Applied Biosystems ${ }^{\prime \prime}$ ). The amplifications efficiency calculation was performed automatically through Software 7500 Fast v2.0.6 (Applied Biosystems ${ }^{\text {t" }}$ ) using the Slope obtained in the linear regression from the following formula: [Efficiency $\left.(E)=10^{(-1 / \text { slope })}-1\right] \times 100 \%[38,39]$.

\section{Standard curve of the real-time PCR essay (qPCR)}

In the assembly of the standard curve essay a standard sample (defined concentration) was prepared for using in the quantification of CABMV in plants. Initially, a total RNA sample was used $\left(100 \mathrm{ng} . \mathrm{\mu L}^{-1}\right)$ of $P$. edulis 40 DAl. The cDNA synthesis of the sample was proceeded (4 repetitions) and then four PCR reactions were performed for final volume of $50 \mu \mathrm{L}$, next $5.0 \mu \mathrm{L}$ of each reaction in agarose gel $2 \%$ was applied (verify presence of unique amplicons). The samples were gathered originating two samples with $90 \mu \mathrm{L}$ each, and the final products of the PCR were purified with KitPureLink ${ }^{\mathrm{T}}$ PCR Purification, following the manufacturer specifications (Invitrogen $\left.{ }^{\text {'I") }}\right)$. After purification, the samples were again gathered $(80 \mu \mathrm{L})$. The sample was quantified in agarose gel $1 \%(5.0 \mu \mathrm{L})$ and spectrophotometer (3x) (NanoVue ${ }^{\text {tu }}$ Plus; GE Healthcare), obtaining an approximate concentration of $30 \mathrm{ng} . \mathrm{\mu L}^{-1}$.

The standard curve was assembled with five points ( $10^{9}$ to $10^{5}$ copies) of serial dilutions in ten times; $1: 10,1: 100,1: 1000$ and 1:10.000 (1 to $\left.0.0001 \mathrm{ng} \mathrm{LL}^{-1}\right)$. Subsequently linear regression calculation was applied regarding the Cycle threshold variables (Ct) vs. Log of CDNA concentrations (ng. $\left.\mathrm{LL}^{-1}\right)$ to determine the correlation coefficient $\left(\mathrm{R}^{2}\right)$ among the points of each dilution and the curve inclination (Slope) [39]. The concentration of the number of copies of CABMV (copies. $\mu \mathrm{L}^{-1}$ ) in each point of the serial 
dilution was determined with application of the following formula: Copy Numbers $\left(\mathrm{CN} \cdot \mathrm{L}^{-1}\right)=($ Sample

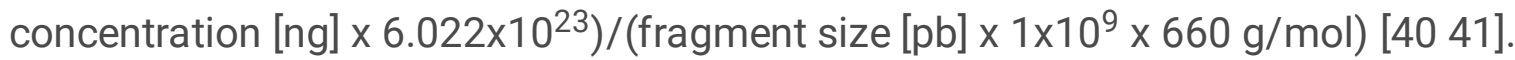

\section{Detection and quantification of CABMV by real-time PCR (qPCR)}

The qPCR reactions to quantify CABMV in asymptomatic plants and asymptomatic reinoculated plants were performed in the equipment '7500 Fast Real-Time PCR System' (Applied Biosystems s', Foster City, USA) on a 'MicroAmp ${ }^{\text {tm }}$ Fast Optical 96-Well Reaction Plate' (0.1 mL; Applied Biosystems ${ }^{\text {th }}$ ), programmed for analysis of the type "Quantitation - Standard Curve".

The plate was mounted with $1.0 \mu \mathrm{L}$ of cDNA (generated from $100 \mathrm{ng} . \mu \mathrm{L}^{-1}$ of total RNA), $0.5 \mu \mathrm{L}$ of each primer at $2.0 \mu \mathrm{M}$ (final concentration of $0.1 \mu \mathrm{M}$ ), $5.0 \mu \mathrm{L}$ of GoTaq ${ }^{\circledR}$ qPCR Master Mix (Promega ${ }^{\circledR}$ ), $0.2 \mu \mathrm{L}$ of CXR Reference Dye and $2.8 \mu \mathrm{L}$ of water (q.s. $10 \mu \mathrm{L}$ ) (Nuclease-Free Walter - Promega ${ }^{\circledR}$ ). To ensure that there was no unspecific amplification or contamination in the preparation of the reactions, it was used as negative control a cDNA sample derived from plant not inoculated with CABMV ( $P$. edulis) and control without mold was also included (Non Template Control - NTC). All reactions for each of the samples were conducted in technical triplicates. The program used for amplification of the CABMV coat protein gene was the standard of the equipment in Standard mode, following the stages: incubation at 50

${ }^{\circ} \mathrm{C}$ for $2 \mathrm{~min}$, activation of taq DNA polymerase at $95^{\circ} \mathrm{C}$ for $10 \mathrm{~min}$, followed by 40 denaturation cycles at $95^{\circ} \mathrm{C}$ for $15 \mathrm{sec}$, annealing of the primers and extension at $60^{\circ} \mathrm{C}$ for $1 \mathrm{~min}$. To check the occurrence of primers dimers, specificity in generating unique amplicons and determine the amplicons average fusion point, the samples were submitted to analysis of the dissociation curve at $95^{\circ} \mathrm{C}$ for 15 seconds, $60^{\circ} \mathrm{C}$ for $20 \mathrm{sec}$ and $95^{\circ} \mathrm{C}$ for $15 \mathrm{sec}$.

After end of the qPCR reaction and dissociation curve, the technical triplicates of each sample were gathered in a single sample. Then $4.0 \mu \mathrm{L}$ of dye was applied ( $5 \mathrm{X}$ Green GoTaq ${ }^{\circledR}$ - Promega ${ }^{\text {th }}$ ) to the reaction products and it was applied in agarose gel $2 \%$, submitted to electric field $(80 \mathrm{~V})$ for $1 \mathrm{~h} 30$ minutes. Therefore, the gel was photo documented to view the presence or absence of amplicons. The fragments size was determined by means of the molecular weight marker $(5.0 \mu \mathrm{L})$ of $100 \mathrm{pb}\left(\mathrm{Ludwig}^{\mathrm{m}}\right)^{\mathrm{m}}$.

\section{Design and Data Analysis}

The experimental design used was entirely randomized considering each of the 25 plants inoculated as a repetition. Other five plants were maintained as control (not inoculated with CABMV). The control plants (of all species) and the asymptomatic plants of $P$. edulis were not considered in the severity analyses.

The means of the disease index (DI\%) in each evaluation period $(12,19,26,33$ and $40 \mathrm{DAl})$ were plotted in logarithmic curves to determine the disease evolution in the twelve Passiflora species and in the three hybrids (inter and intraspecific). To calculate the rate of viruses progress in the leaves, the severity values (DI \%) were used due to the five evaluation time for species with symptoms ( $P$. mucronata, $P$. miersii, $P$. cincinnata, P. gibertii, Passiflora sp., P. edulis, $P$. alata, intraspecific hybrid and interspecific hybrid $\left[F_{1}\right.$ and 
$\left.\left.\mathrm{BC}_{3}\right]\right)$. The original severity or linearized data $(\mathrm{Y}=$ severity/100), were tested by the Gompertz empirical models $(Y=-n n[(y)])$, Monomolecular $(Y=\ln [1 /(1-y)])$ and Logistic $(Y=\ln [y /(1-y)])$ and adjusted for simple linear regression models [42]. Determination of $R^{2}$ and exponit, logit, monit and gompit coefficients were performed through a regression among real values and evaluation period in days (DAI). They were adjusted according to the original or linearized data, obtaining the determination coefficients $\left(R^{2}\right)$ of the regression analysis [42]. Using the best adjustment, the disease progress rate was estimated $(r)$, and determined by the ' $b$ ' (angular coefficient) parameter of the regression equation $\left(\mathrm{R}^{2}\right)$ and by biological interpretations of the data.

The DI (\%) estimates at 40 DAl were used for the comparison of averages by the Scott-Knott test $(p \leq 0.05)$. From the DI (\%) at $40 \mathrm{DAl}$, the intervals were generated for the classification of genotypes such as: resistant - R (DI varying from $0.0-15.9 \%$ ), moderately resistant - MR (DI varying from $16.0-31.9 \%$ ), susceptible - S (DI varying from $32.0-50.9 \%$ ) and highly susceptible - HS (DI $\geq 51.0 \%$ ). The analyses were performed in $\mathrm{R}$ environment using the 'ExpDes.pt' package [43]. The grouping of genotypes was performed based on the Gower index [44] and hierarchical grouping method Unweighted Pair Group Method with Arithmetic Mean (UPGMA). The dissimilarity matrix was obtained with the Genes program [45] and from the matrix the MEGA7.0 program was used to obtain the dendrogram [46].

After the qPCR reactions for asymptomatic inoculated species, the raw data were exported in Excel worksheet $\left(\right.$ Microsoft $\left.{ }^{\circledR}\right)$, treated, and the estimated viral load in the species were determined from the average value of the viral $\mathrm{CDNA}$ quantity $\left(\mathrm{ng} \cdot \mathrm{\mu L}^{-1}\right.$ ) having as parameter the values relative to each point of the standard curve and after the calculations the number of viral copies was converted to Log 10 scale.

\section{Results}

\section{Temporal progress of CABMV in Passiflora species}

Considering the evolution of the disease, it was null for the species belonging to group 1 ( $P$. suberosa, $P$. setacea, P. pohlii, P. malacophylla, P. bahiensis, P. gibertii and P. miersii) and stable in group $2(P$. mucronata and $P$. cincinnata). The evolution of the disease was more progressive in the species of group 3 (P. alata, $P$. edulis, Interspecific hybrid - $\mathrm{BC}_{3}$, Interspecific hybrid - $\mathrm{F}_{1}$ and Passiflora sp.) and of group 4 (Intraspecific hybrid) (Fig. 5).

Regarding the disease progress rate based on the values of or among pairs of species (Table 2), it was possible to verify significant differences among the disease progress rates being lower in $P$. cincinnata than in $P$. alata and Passiflora sp. The species $P$. gibertii presented lower progress rate compared to the intraspecific hybrid, Passiflora sp. and $P$. alata, but with higher rate when compared to $P$. miersii and $P$. mucronata species. On the other hand, $P$. miersii and $P$. mucronata presented lower rate compared to intraspecific hybrids; $P$. alata; $P$. edulis and Passiflora sp., while the interspecific hybrid $\left(\mathrm{F}_{1}\right)$ presented 
higher rate than $P$. mucronata. $P$. miersii and $P$. mucronata species obtained higher rates compared to $P$. cincinnata (Table 2). Other comparisons did not present significant differences (Table 2).

Table 2 Comparisons of the viruses progress rates ( and $)^{1}$ among the species evaluated.

\begin{tabular}{|c|c|c|c|c|c|}
\hline \multirow[t]{2}{*}{ Combinations (species vs. species) } & \multicolumn{2}{|l|}{ Limit } & \multirow[t]{2}{*}{$\theta 1$} & \multirow[t]{2}{*}{$\theta 2$} & \multirow[t]{2}{*}{ Sig. $(p \leq 0.05)$} \\
\hline & Lowest & Highest & & & \\
\hline P. cincinnata vs. P. alata & 0.00712 & 0.01408 & 0.00489 & $\underline{0.01549}$ & * \\
\hline P. cincinnata vs. P. miersii & 0.00454 & 0.00690 & $\underline{0.00489}$ & -0.00083 & * \\
\hline P. cincinnata vs. P. mucronata & 0.00362 & 0.00755 & $\underline{0.00489}$ & -0.00069 & * \\
\hline P. cincinnata vs. Passiflora sp. & 0.00719 & 0.02030 & 0.00489 & $\underline{0.01864}$ & * \\
\hline P. gibertii vs. Intra $\mathrm{H}$. & 0.00202 & 0.01364 & 0.00188 & $\underline{0.00971}$ & * \\
\hline P. gibertii vs. P. alata & 0.01012 & 0.01710 & 0.00188 & $\underline{0.01549}$ & * \\
\hline P. gibertii vs. P. miersii & 0.00150 & 0.00392 & $\underline{0.00188}$ & -0.00083 & * \\
\hline P. gibertii vs. P. mucronata & 0.00059 & 0.00455 & $\underline{0.00188}$ & -0.00069 & * \\
\hline P. gibertii vs. Passiflora sp. & 0.02331 & 0.01020 & 0.00188 & $\underline{0.01864}$ & * \\
\hline P. miersii vs. Intra $\mathrm{H}$. & 0.00482 & 0.01626 & -0.00083 & $\underline{0.00971}$ & * \\
\hline P. miersii vs. P. alata & 0.01298 & 0.01966 & -0.00083 & $\underline{0.01549}$ & * \\
\hline P. miersii vs. P. edulis & 0.00021 & 0.01914 & -0.00083 & $\underline{0.00885}$ & * \\
\hline P. miersii vs. Passiflora sp. & 0.01299 & 0.02595 & -0.00083 & $\underline{0.01864}$ & * \\
\hline P. mucronata vs. Intra $\mathrm{H}$. & 0.00447 & 0.01634 & -0.00069 & $\underline{0.00971}$ & * \\
\hline P. mucronata vs. P. alata & 0.01249 & 0.01987 & -0.00069 & $\underline{0.01549}$ & * \\
\hline P. mucronata vs. P. edulis & -0.00006 & 0.01913 & -0.00069 & $\underline{0.00885}$ & * \\
\hline P. mucronata vs. Passiflora sp. & 0.01266 & 0.02600 & -0.00069 & $\underline{0.01864}$ & * \\
\hline P. mucronata vs. Inter $\mathrm{H}$. $\left(\mathrm{F}_{1}\right)$. & -0.00421 & 0.02331 & -0.00069 & $\underline{0.00886}$ & * \\
\hline Other 31 combinations & - & - & - & - & ns \\
\hline
\end{tabular}

${ }^{1}$ Values greater of the disease progress rate ( or are underlined in the table.

Classification of Passiflora species and genotypes regarding the severity of CABMV

Based on the severity results associated with the disease index (DI\%) at $40 \mathrm{DAl}$, it was observed genetic variability among the Passiflora spp. and intra and interspecific hybrids, with variation in the DI from 0.0 
to $70.80 \%$, and 26 genotypes (20.3\%) were classified as resistant (R; DI ranging from 0.0 to $15.75 \%$ ). Considering the reaction within this same group, it was highlighted the BGP152 (P. suberosa), BGP170 ( $P$. malacophylla), BGP434, BGP244 and BRS Pérola do Cerrado (P. setacea), BGP454 (P. pohlii) and BGP477 (P. bahiensis) genotypes, which did not manifest typical CABMV symptoms (DI: 0.0\%). Other 12 genotypes (9.4\%) were moderately resistant (MR; DI ranging from 16.3 to $31.1 \%), 42$ (32.8\%) susceptible (S; DI ranging from 33.3 to $50.9 \%$ ) and 48 (37.5\%) highly susceptible (HS; DI ranging from 51.2 to $70.8 \%$ ) (Figs. 6a, b and Sup. 1).

Assuming the $P$. edulis genotypes, only the BGP124 was considered as moderately resistant, with DI of $31.11 \%$. Other 53 genotypes (41.4\%) presented some degree of susceptibility, of which $27(21.1 \%)$ were susceptible and $26(20.3 \%)$ were highly susceptible. All genotypes belonging to the intra-specific hybrids, interspecific hybrids (F1) and interspecific hybrids of the third generation of backcrossing $\left[\mathrm{BC}_{3}(P\right.$. edulis $\mathrm{x}$ P. cincinnata) $\times$ P. edulis) were classified as susceptible and highly susceptible (Fig. 6 and Sup. 1). The genotypes used as controls for resistance reactions (BGP200) and susceptibility ( $c v$. BRS Gigante Amarelo) presented severity within the expected level, with mean DI of $15.30 \%$ and $62.20 \%$, respectively.

Among the species evaluated, seven (46.67\%) were classified as resistant ( $P$. bahiensis, $P$. malacophylla, P. pohlii, P. setacea, P. suberosa, P. gibertii and P. miersii) with DI of 0.0 to $14.80 \%$; two species $(13.33 \%)$ were classified as moderately resistant ( $P$. cincinnata and $P$. mucronata) with DI of 16.10 to $18.70 \%$; three (20\%) (Passiflora sp., P. edulis and interspecific hybrids of the third generation of backcrossing $\left[\mathrm{BC}_{3}\right]$ ) were classified as susceptible to CABMV, with DI that ranged from 37.60 to $50.40 \%$ and three (20\%) were considered highly susceptible to CABMV with mean DI of 51.90 to $64.90 \%$ (hybrids $\left[\mathrm{F}_{1}\right]$, P. alata and intraspecific hybrids) (Fig. 6c).

\section{Severity and classification of genotypes reinoculated with CABMV}

The reinoculated genotypes demonstrated typical viruses symptoms, specifically those that are belonging to the species $P$. gibertii, $P$. cincinnata, $P$. mucronata, $P$. miersii and the interspecific hybrid (OTH-137), the latter with $100 \%$ incidence in reinoculated plants (Table 3 ). The average severity of 34 reinoculated genotypes ranged from 0.0 to $60.74 \%$ (Table 3 ). Among the genotypes evaluated $55.88 \%(n=19)$ were considered as resistant, with DI ranging between 0.0 and $15.83 \% .15 .83 \%$. Within this same group, the BGP152 (P. suberosa), BGP170 (P. malacophylla), BRS Pérola do Cerrado, BGP434 and BGP244 ( $P$. setacea), BGP454 (P. pohlii) and BGP477 ( $P$. bahiensis) genotypes even after reinoculation did not manifest symptoms of the disease, maintaining the classification as resistant (Table 3). Other 13 genotypes (38.24\%) were classified as moderately resistant, with DI of 17.50 to $30.29 \%$ and two genotypes (BGP275 and OTH-137) were classified as susceptible (DI: 36.74\%) and highly susceptible (DI: $60.74 \%$ ) (Table 3).

Table 3 Minimum, maximum and average severity value (DI) and resistance phenotypic classification of 34 Passiflora spp., reinoculated with the passion fruit woodiness disease (Cowpea aphid-borne mosaic virus - CABMV). 


\begin{tabular}{|c|c|c|c|c|c|c|}
\hline \multirow[t]{2}{*}{ No } & \multirow[t]{2}{*}{ Code $^{\star}$} & \multirow[t]{2}{*}{ Species } & \multicolumn{3}{|c|}{ DI $(\%)^{\mathrm{a}}$} & \multirow[t]{2}{*}{ Class $^{b}$} \\
\hline & & & Min. & Max. & Mean & \\
\hline 1 & BGP152 & P. suberosa & 0.00 & 0.00 & $0.00 a$ & $\mathrm{R}$ \\
\hline 2 & BGP170 & P. malacophylla & 0.00 & 0.00 & $0.00 a$ & $\mathrm{R}$ \\
\hline 3 & BRS Pérola do Cerrado & P. setacea & 0.00 & 0.00 & $0.00 a$ & $\mathrm{R}$ \\
\hline 4 & BGP434 & P. setacea & 0.00 & 0.00 & $0.00 a$ & $\mathrm{R}$ \\
\hline 5 & BGP454 & P. pohlii & 0.00 & 0.00 & $0.00 a$ & $\mathrm{R}$ \\
\hline 6 & BGP477 & P. bahiensis & 0.00 & 0.00 & $0.00 a$ & $\mathrm{R}$ \\
\hline 7 & BGP244 & P. setacea & 0.00 & 0.00 & $0.00 \mathrm{a}$ & $\mathrm{R}$ \\
\hline 8 & BGP085 & P. gibertii & 0.00 & 33.33 & $5.18 a$ & $\mathrm{R}$ \\
\hline 9 & BGP421 & P. cincinnata & 0.00 & 26.67 & $7.33 b$ & $\mathrm{R}$ \\
\hline 10 & BGP300 & P. cincinnata & 0.00 & 33.33 & $8.23 b$ & $\mathrm{R}$ \\
\hline 11 & BGP290 & P. cincinnata & 0.00 & 33.33 & $11.42 \mathrm{~b}$ & $\mathrm{R}$ \\
\hline 12 & BGP243 & P. cincinnata & 0.00 & 33.33 & $12.82 \mathrm{~b}$ & $\mathrm{R}$ \\
\hline 13 & BGP422 & P. cincinnata & 0.00 & 33.33 & $12.85 b$ & $\mathrm{R}$ \\
\hline 14 & BGP008 & P. gibertii & 0.00 & 60.00 & $13.33 b$ & $\mathrm{R}$ \\
\hline 15 & BGP414 & P. gibertii & 0.00 & 33.33 & $13.33 b$ & $\mathrm{R}$ \\
\hline 16 & BGP389 & P. cincinnata & 0.00 & 40.00 & $13.33 b$ & $\mathrm{R}$ \\
\hline 17 & BGP268 & P. cincinnata & 0.00 & 66.67 & $14.22 \mathrm{~b}$ & $\mathrm{R}$ \\
\hline 18 & BGP478 & P. mucronata & 0.00 & 33.33 & $14.44 b$ & $\mathrm{R}$ \\
\hline 19 & BGP114 & P. mucronata & 0.00 & 33.33 & $15.83 b$ & $\mathrm{R}$ \\
\hline 20 & BGP279 & P. cincinnata & 0.00 & 26.67 & $17.50 \mathrm{c}$ & MR \\
\hline 21 & BGP453 & P. miersii & 0.00 & 33.33 & $18.33 c$ & MR \\
\hline 22 & BGP480 & P. cincinnata & 0.00 & 53.33 & $19.04 \mathrm{c}$ & MR \\
\hline 23 & BGP483 & P. cincinnata & 0.00 & 40.00 & $19.33 c$ & MR \\
\hline 24 & BGP246 & P. cincinnata & 0.00 & 33.33 & $19.99 \mathrm{c}$ & MR \\
\hline 25 & BGP276 & P. cincinnata & 0.00 & 40.00 & $20.55 c$ & MR \\
\hline
\end{tabular}




\begin{tabular}{|lllllll|}
26 & BGP308 & P. cincinnata & 0.00 & 53.33 & $20.95 \mathrm{c}$ & $\mathrm{MR}$ \\
\hline 27 & BGP398 & P. cincinnata & 0.00 & 60.00 & $21.25 \mathrm{c}$ & $\mathrm{MR}$ \\
\hline 28 & BGP297 & P. cincinnata & 0.00 & 33.33 & $23.80 \mathrm{c}$ & $\mathrm{MR}$ \\
\hline 29 & BGP286 & P. cincinnata & 0.00 & 86.67 & $24.16 \mathrm{c}$ & $\mathrm{MR}$ \\
\hline 30 & BGP274 & P. cincinnata & 0.00 & 66.67 & $25.55 \mathrm{c}$ & $\mathrm{MR}$ \\
\hline 31 & BGP349 & P. cincinnata & 0.00 & 33.33 & $28.33 \mathrm{~d}$ & $\mathrm{MR}$ \\
\hline 32 & BGP294 & P. cincinnata & 0.00 & 33.33 & $30.29 \mathrm{~d}$ & $\mathrm{MR}$ \\
\hline 33 & BGP275 & P. cincinnata & 33.33 & 40.00 & $36.74 \mathrm{~d}$ & $\mathrm{~S}$ \\
\hline 34 & OTH-137 & Interspecific H. & 46.67 & 80.00 & $60.74 \mathrm{e}$ & $\mathrm{HS}$ \\
\hline
\end{tabular}

${ }^{*}$ Code of Passion fruit Germplasm Active Bank of Embrapa Mandioca e Fruticultura. ${ }^{a} \mathrm{DI}(\%)=$ Disease index at 40 days after reinoculation (DARI) of asymptomatic plants; ${ }^{\mathrm{b}} \mathrm{R}=$ resistant; $\mathrm{MR}=$ moderately resistant; $\mathrm{S}=$ susceptible; $\mathrm{HS}$ = highly susceptible. Mean followed by the same letter in the column belong to the same group by the Scott-Knott test $(p \leq 0.05)$.

\section{Detection of CABMV by qualitative RT-PCR}

The molecular analysis by qualitative RT-PCR and primers CABMV/M1MX3726_F/CABMV/M1MX5039_R confirmed the viral infection in symptomatic inoculated plants, with amplification of the genomic fragments related to the cylindrical inclusion region (Cl) of CABMV with expected size of $1311 \mathrm{pb}$ (Fig. 7a). In asymptomatic inoculated plants and negative control, the systemic replication of CABMV was not confirmed (Figs. $7 \mathrm{~b}$ and c). Asymptomatic plants were submitted to real time quantitative PCR analysis (qPCR) to confirm the infection (Fig. 7b).

Fig. 7 Products of amplification by RT-PCR in agarose gel 1\% using primers for the genomic fragment of the cylindrical inclusion of CABMV (Cowpea aphid-borne mosaic virus) of $1311 \mathrm{pb}$. A) pool of leaf samples of symptomatic inoculated plants (S-IP) at 40 days after inoculated (DAI); B) pool of leaf samples of asymptomatic inoculated plants (A-IP); C) pool of leaf samples of not inoculated plants with CABMV (NIP, negative controls). PC: Positive control (Matrices plants of $P$. edulis with CABMV symptoms - cDNA $\left.200 \mathrm{ng} \cdot \mathrm{\mu L}^{-1}\right) \cdot \mathrm{M}=$ Molecular DNA Marker Ladder of $1 \mathrm{~Kb}$ (Invitrogen $\left.{ }^{\mathrm{Tu}}\right)$. $P$. ed = Passiflora edulis, Intra $\mathrm{H} .=$ Intraspecific Hybrid; Inter $\mathrm{H} .=$ Interspecific Hybrid; $P$. ala $=P$. alata; $P$. mie $=$ P. miersii; $P . \quad m u c=P$. mucronata; $P$. $\operatorname{cin}=P$. cincinnata; $P$. gib $=P$. gibertii, $P$. set $=P$. setacea; $P$. poh $=P$. pohlii; $P$. mala $=P$. malacophylla; $P$. sub $=P$. suberosa; $P$. bah $=$ P. bahiensis. *Unregistered leaf tissue (Passiflora sp BGP482).

\section{Standardization of the qPCR technique for CABMV quantification}


The amplifications with the primer qCABMV07 were quite uniform (Fig. 8a) and the amplification efficiency obtained Slope $=-3.53$, determination coefficient $\left(R^{2}\right)=0.997$, Efficiency $(E)=91.96 \%$ and the standard deviation (SD) of the Cycle threshold (Ct) of the technical triplicates in each dilution $\left(10^{10}\right.$ to $10^{6}$ ) was 0.08 to 0.32 (Fig. 8b). The dissociation curve of amplifications was uniform, without formation of primers dimers or nonspecific peaks (Fig. 8c).

The essay of the purified PCR standard curve was prepared with seven dilution points $\left(10^{10}, 10^{9}, 10^{8}, 10^{7}\right.$, $10^{6}, 10^{5}$ and $10^{4}$ copies). However, points $10^{10}(10 \mathrm{ng} . \mu \mathrm{L}-1)$ and $10^{4}\left(0.001 \mathrm{ng} . \mu \mathrm{L}^{-1}\right)$ were disregarded. Point $10^{10}$ despite presenting amplifications of replicates considerable uniform, did not present linearity in the spacing of -3.32 between the dilutions $10^{10}$ and $10^{9}$. Point $10^{4}$ did not present uniformity in the amplifications of the technical repetitions (Figs. 9a and b). Linear regression ratio between the mean values of the $\mathrm{Ct}$ and the concentration of the CABMV genic product was observed with determination coefficient $\left(R^{2}=0.998\right)$ and an Slope of -3.33 , demonstrated efficiency $(E)$ of $99.37 \%$ of the qPCR reaction (Fig. 9a). The dissociation curve of amplifications also demonstrated that there was high specificity of qPCR for the standard curve, observed through the uniformity of amplifications, formation of unique peaks and without presence of primers dimers (Fig. 9b). The quantification of the number of copies of part of the CABMV coat protein gene in the serial dilutions of the standard curve was equivalent to $3.28 \mathrm{x}$ $10^{33}$ to $3.28 \times 10^{29}$ copies. $\mu \mathrm{L}^{-1}$ with mean values of the $\mathrm{Ct}$ of the technical triplicates obtained in a very reproducible way and standard deviation (SD) of the Ct varied from 0.03 to 0.34 (Table 4). These quantifications were used for absolute quantification of the viral load in the evaluated species.

Table 4 Mean values and standard deviation (SD) of the Cycle threshold (Ct) of the three technical replicates and number of copies of the CABMV virus (Copies. $\mu \mathrm{L}^{-1}$ ) expressed in $\mathrm{Log}^{10}$ scale of each serial dilution of the standard curve of the CABMV coat protein gene.

\begin{tabular}{|c|c|c|c|c|c|}
\hline Dilutions & $10^{9}$ & $10^{8}$ & $10^{7}$ & $10^{6}$ & $10^{5}$ \\
\hline$C t \pm S D$ & $20.15 \pm 0.07$ & $23.55 \pm 0.03$ & $26.86 \pm 0.09$ & $30.44 \pm 0.34$ & $33.39 \pm 0.28$ \\
\hline $\mathrm{N}^{0}$ Copies. $\mu \mathrm{L}^{-1}$ & $3.28 \times 10^{33}$ & $3.28 \times 10^{32}$ & $3.28 \times 10^{31}$ & $3.28 \times 10^{30}$ & $3.28 \times 10^{29}$ \\
\hline
\end{tabular}

\section{Detection and quantification of CABMV by real-time PCR (qPCR)}

The qPCR reactions in asymptomatic inoculated plants (Fig. 3b), demonstrate quality and precision in the amplification obtaining curve inclination (Slope) of -3.28 , determination coefficient $\left(R^{2}\right)$ of 0.998 , efficiency (E) of $101.74 \%$ and the dissociation curve demonstrated the lack of nonspecific products and absence of primer dimers (Fig. 10a). The standard deviation of the Ct of the three technical replicates of each of the samples varied from 0.07 to 0.65 (Fig. 10b).

Regarding the quantity of CAMBV in asymptomatic species, it was observed variation of $1 \times 10^{0}$ to $1.59 \mathrm{x}$ $10^{31}$ copies of viruses per microliter (Fig. 10b). There was little variation in the number of copies of the 
virus for the interspecific hybrid (OTH-137) and the species $P$. cincinnata, $P$. gibertii and $P$. miersii, with $1.59 \times 10^{31}, 1.41 \times 10^{31}, 1.33 \times 10^{31}$ and $1.11 \times 10^{31}$ copies of viruses. $\mu \mathrm{L}^{-1}$, respectively (Fig. 10b). Regarding the P. mucronata, $P$. setacea and $P$. malacophylla species, it was observed lower quantity of virus than the previously mentioned species, with $1.18 \times 10^{30}, 1.34 \times 10^{29}$ and $4.35 \times 10^{28} \mathrm{copies}^{\mathrm{\mu L}} \mathrm{L}^{-1}$, respectively (Fig. 10b). In the $P$. pohlii, $P$. suberosa and $P$. bahiensis species, it was not detected fragment corresponding to CABMV, showing that there was no infection after two inoculation attempts (Figs. 10a and b). The result in agarose gel confirms the specificity in the amplifications, with unique amplicons of expected size of $121 \mathrm{pb}$ in the interspecific hybrid (OTH-137) and the $P$. cincinnata, $P$. gibertii, P. miersii, $P$. mucronata, P. setacea and P. malacophylla species (Fig. 10c).

From the molecular analysis of RT-PCR there was confirmation of the viral infection in plants that presented symptoms after the third and fourth reinoculation (Fig. 11a). However, numerous plants of $P$. cincinnata, P. gibertii, P. miersii, P. mucronata, P. setacea, P. malacophylla, P. suberosa, P. pohlii and P. bahiensis did not manifest viruses symptoms, and, therefore, were submitted to the analysis of qPCR, except for interspecific hybrid (OTH-137) that had all plants with symptoms.

The parameters of quality definition and accuracy of the qPCR technique for reinoculated asymptomatic plants (Fig. 3c) demonstrated reproductive and accurate results, obtained Slope $=-3.35$, determination coefficient $\left(R^{2}\right)=0.998$ and Efficiency $(E)=98.84 \%$, and the dissociation curves also demonstrated high specificity of amplification of the CABMV coat protein gene (Fig. 11b). The standard deviation of the Ct of the three technical replicates of each of the samples varied from 0.02 to 0.92 (Fig. 11c). The analysis of qPCR in reinoculated asymptomatic plants (Fig. 3d), detected CABMV in P. cincinnata, P. gibertii, P. miersii, P. mucronata, $P$. setacea, $P$. malacophylla and $P$. suberosa, but was not detected in $P$. pohlii and $P$.

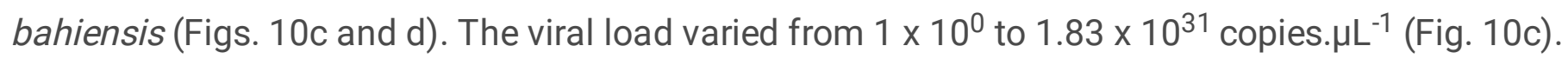

The variation in the number of copies of the virus among the evaluated species was low, with $1.83 \times 10^{31}$ for $P$. cincinnata, $1.81 \times 10^{31}$ in $P$. gibertii, $1.78 \times 10^{31}$ compared to $P$. miersii and $1.59 \times 10^{31}$ for $P$. mucronata. $P$. setacea and $P$. malacophylla species presented mild decrease in the viral load compared to the species mentioned above, with $3.49 \times 10^{30}$ and $2.11 \times 10^{29}$ copies of viruses. $\mu \mathrm{L}^{-1}$. In $P$. suberosa, there

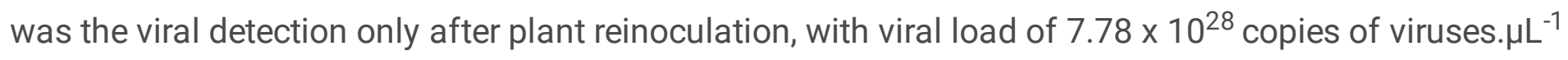
(Fig. 10c). The result demonstrated in Fig. 10d, evidences the formation of unique amplicons of CABMV coat protein of $121 \mathrm{pb}$ in species $P$. cincinnata, $P$. gibertii, $P$. miersii, $P$. mucronata, $P$. setacea, $P$. malacophylla and $P$. suberosa.

\section{Discussion}

Temporal progress and identification of resistance source in Passiflora spp. species and genotypes

The differences in evolution curves and viruses progress rates (Fig. 5 and Table 2) demonstrate high variability of Passiflora spp. for resistance/susceptibility to CABMV. The results of Spadotti et al. [16] demonstrated that the incubation time of CABMV in P. edulis plants (FB-200) is, on average, 8 DAI. 
However, the incubation time of CABMV for most of the Passiflora spp. it is not known with accuracy, and the initial expression of symptoms is dependent on the plant age, genotype or isolated used and affected directly by environmental conditions and nutrition of plants $[16,28]$. In the initial evaluation (12 DAl), most species had already manifested the typical symptoms of the disease, however, it is possible that some of the species had already expressed symptoms before this period. P. suberosa, P. setacea, P. pohlii, $P$. malacophylla and $P$. bahiensis species did not manifest symptoms over time and Passiflora sp. was at 19 DAl.

Species classified as resistant and moderately resistant are wild, and naturally carry resistance alleles [47] and in this study 38 genotypes $(29.70 \%)$ are in these two classes. Highlighting the species such as $P$. bahiensis (BGP477), P. malacophylla (BGP170), P. pohlii (BGP454), P. setacea (BGP244, BGP434 and BRS Pérola do Cerrado) and $P$. suberosa (BGP152) that did not manifest viruses symptoms in the leaves (DI: $0.0 \%$ ). On the other hand, P. gibertii (BGP085, BGP008 and BGP414), P. miersii (BGP453), P. mucronata (BGP478 and BGP114) and P. cincinnata species (BGP421, BGP422, BGP279, BGP276, BGP290, BGP300, BGP243, BGP480, BGP481, BGP246, BGP349 and BGP268) exhibited light mosaic throughout the evaluations, indicating tolerance to CABMV virus (Fig. 6c). According to Oliveira et al. [22] a resistant genotype can present mild viruses symptoms, but has mechanisms that prevents the multiplication of the pathogen. With this in mind, genotypes that presented mild symptoms (DI from 4.19 to $15.75 \%$ ) should be considered for selection aiming resistance to CABMV from interspecific hybridization. Previous studies reported resistance to CABMV in genotypes belonging to $P$. setacea $[22,48]$, $P$. cincinnata [22, 24], $P$. gibertii [24] and immunity in $P$. suberosa [21]. This research is pioneer in reporting immunity to CABMV in $P$. bahiensis and $P$. pohlii and moderately resistant in $P$. miersii, amplifying the number of wild species of Passiflora spp. characterized for CABMV reaction.

Species with null or low severity can be used to intensify the genetic improvement programs of Passiflora via interspecific crosses. However, interspecific hybridizations with commercial species, in some cases, may not succeed due to differences in the number of chromosomes $(P$. pohlii [ $2 \mathrm{n}=12$ and 36$]$ and $P$. suberosa $[2 n=12,24$ and 36]) and belong to different subgenera $[49,50]$ and in the same subgenre can occur barriers of crossings or lack of synchronism in the flowering [51]. However, in some cases the interspecific barriers of incompatibility are relatively fragile, and there may be success in hybridization [52].

The understanding of cytogenetic aspects involved in the crossing of $P$. edulis $\times$ P. cincinnata demonstrate the possibility of obtaining hybrids and thus transferring resistance alleles or other characters of the wild species [53]. Studies using $P$. setacea and $P$. cincinnata (both $2 n=18$ ), as donors of CABMV resistance alleles for $P$. edulis $(2 n=18)$ were also successful $[18-20,25,54]$. P. malacophylla and $P$. bahiensis species (belonging to the genus Passiflora) present potential for using genetic improvement programs of passion fruit, because they are resistant to CABMV (DI: $0.0 \%$ ) and have chromosomal analogy with $P$. edulis $(2 \mathrm{n}=18)$ [55], opening possibilities of obtaining resistant commercial hybrids. However, complementary studies should be performed in these two species to confirm the real chance of obtaining viable hybrids. 
It was observed relation between incidence and severity of CABMV for most of the evaluated genotypes, already in P. mucronata (BGP479) and P. edulis (BGP124) even with incidence of $100 \%$ the plants presented only mild mosaic (grade 2), being classified as moderately resistant (Sup. 1 ). The occurrence of this case allows to indicate that the incidence cannot always be related to the severity.

Most of the genotypes of $P$. edulis presented susceptibility to CABMV (Fig. 6), except for the BGP124 genotype that was moderately resistant. Results in the literature demonstrated different resistance levels among $P$. edulis genotypes, being classified from resistant to highly susceptible $[22,24,56,57]$. This indicates there is intraspecific genetic variability in the resistance to CABMV. For this reason, the evaluation of $P$. edulis genotypes in GABs should be performed to explore low severity levels of the disease, and thus reduce the time for obtaining resistant cultivars $[18,24,25]$.

The susceptibility observed in the six intraspecific hybrids of $P$. edulis (H09-111, H09-02, H09-110, H09-09, H09-112 and H09-158) is directly related to the selection of parentals, taking into consideration only agronomic attributes of vigor and production $[58,59]$. Interspecific hybrids of the third generation of backcrossing $\left(\mathrm{BC}_{3}\right)$ despite having contrasting genitors, BGP330 ( $P$. edulis, susceptible) and BGP077 ( $P$. cincinnata; resistant) [24] did not present resistance to CABMV, probably related to the low number of evaluated progenies $(n=21)$ or fact that there are few genes or resistance losses in $B_{3}$, since $93.75 \%$ of the genome involved in the backcrossing belongs to the susceptible recurrent genitor ( $P$. edulis). Fonseca et al. [60] also did not verify the resistance to CABMV in genotypes of the fourth and fifth generation of backcrossing $\left(\mathrm{BC}_{4}\right.$ and $\left.\mathrm{BC}_{5}\right)$ involving $P$. edulis $\times$ P. setacea, due to the loss of resistance as new backcrossing are performed, probably due to the polygenic heritage of the character [18-20]. Therefore, that there are gains associated with resistance to CABMV it is necessary to evaluate a very large number of progenies as the backcrossing generations advance [19]. However, the genetic heritage for resistance to CABMV of most of the Passiflora species is still unknown, being an open field for researches in genetic improvement programs.

The variation in the resistance level to CABMV within and among the evaluated genotypes can be associated with the genetic variability of the passifloras, since they are self-incompatible plants [51, 61, 62]. Moreover, different studies attribute the passion fruit response to the use of different isolates [21, 56], latency period and virus incubation [16], individual resistance level of genotypes [24], genetic and environmental factors (such as temperature and relative humidity) [19, 25, 63], nutritional condition and age difference among plants [64]. Alone or together, these factors can influence the virulence of the pathogen and in the manifestation of the disease symptoms. In this study many plants were observed without viruses symptoms, especially in wild species. However, some of these factors may not be the cause, since the evaluated genotypes had the same age and the environmental and nutritional conditions were the same.

\section{Conclusions}


Progress rates and mean disease severity in symptomatic plants were lower in $P$. cincinnata, $P$. gibertii, $P$. miersii and $P$. mucronata in relation to the species $P$. edulis, $P$. alata, inter and intraspecific hybrids and Passiflora sp. The accessions belonging to the species $P$. suberosa, P. malacophylla, $P$. setacea, $P$. pohlii e $P$. bahiensis did not manifest visual symptoms of the disease after artificial inoculation. Some asymptomatic plants ( $P$. cincinnata, $P$. gibertii, $P$. miersii and $P$. mucronata) after new inoculation cycles (third and fourth inoculation) had lower mean disease severity in relation to the severity of the symptoms of the two initial inoculations and this may indicate some control mechanism like pre-immunization. The absence of visual symptoms of the disease in some plants or accessions does not indicate immunity, because asymptomatic plants may exhibit systemic infection by CABMV as detected by qPCR analysis. The species $P$. pohlii and $P$. bahiensis even after four inoculations, showed no disease symptoms and no systemic infection of the virus by QPCR analysis, revealing that they are immune to CABMV.

\section{Declarations}

\section{Acknowledgments}

The Coordenação de Aperfeiçoamento de Pessoal de Nível Superior (CAPES) provided a doctoral research grant to the first author (ZSG). The Conselho Nacional de Desenvolvimento Científico e Tecnológico (CNPq) provided a postdoctoral scholarship to the third author (LKSL - PDJ 152109/20196), a research productivity fellowship to the second (ONJ - PQ 312774/2018-4) and fourth author (RXC). The research unit of Embrapa Mandioca e Fruticultura for providing the plant material, infrastructure and technical support for the execution of the research. The Dr. Saulo Alves S. de Oliveira for supporting the analysis of data on disease progress rates. To Dr. Antônio Vargas de O. Figueira and the Centro de Energia Nuclear na Agricultura (CENA - Esalq/USP) for providing laboratory space and technical support for training in quantitative real time PCR analysis (qPCR) of the first author (ZSG).

\section{Authors' contributions}

All authors contributed to writing, as well as toward interpreting the results, revising, and improving the paper. ZSG carried out the installation of the experiment, assessment of the severity of the disease, molecular analysis of virus detection and quantification and writing of the paper. ZSG, ONJ, LKSL and participated in the statistical analysis, organization and elaboration of tables and figures, as well as data interpretation. ONJ, LKSL and RXC corrected the paper. ONJ and RXC were the creators of this research.

\section{Funding}

This work was funded by the Conselho Nacional de Desenvolvimento Cientifico e Tecnológico (CNPq Process 421033/2018-5), Embrapa Mandioca e Fruticultura (Process Embrapa 22.16.04.007.00.00) and Fundação de Amparo à Pesquisa do Estado da Bahia (FAPESB - TO DTE0001/2016).

\section{Compliance with ethical standards}

\section{Conflict of interest}


The authors declare that they have no conflicts of interest.

\section{Ethical standards}

The authors declare that the present work complies with ethical standards of committee on publication ethics (COPE) and complies with the company's ethical standards Universidade Estadual de Santa Cruz and Embrapa Mandioca e Fruticultura.

Code availability Not applicable.

Ethics approval Not applicable.

\section{References}

1. Bernacci LC, Soares-Scott MD, Junqueira NTV, Passos IRDS, Meletti LMM (2008) Passiflora edulis Sims: the correct taxonomic way to cite the yellow passion fruit (and of others colors). Rev Bras Frutic 30:566-576. https://doi.org/10.1590/S0100-29452008000200053

2. Coelho EM, Azevêdo LC, Umza-Guez MA (2016a) Fruto do maracujá: Importância econômica e industrial, produção, subprodutos e prospecção tecnológica. Cad Prospec 9:347. https://dx.doi.org/10.9771/S.CPROSP.2016.009.037

3. IBGE (Instituto Brasileiro de Geografia e Estatística). (2020). Banco de dados agregados. Sistema IBGE de Recuperação Automática - SIDRA. Disponível em: http://www.ibge.gov.br.

4. Melo JF, Reis Figueira A, Moreira CN, Oliveira AC (2015) Recent characterization of Cowpea aphidborne mosaic virus (CABMV) in Bahia State, Brazil, suggests potential regional isolation. Afr J Biotechnol 14:735-744. https://doi/5897/AJB2015.14409

5. Rodrigues LK, Silva LA, Garcêz RM, Chaves AL, Duarte LM, Giampani JS, Eiras M (2015) Phylogeny and recombination analysis of Brazilian yellow passion fruit isolates of Cowpea aphid-borne mosaic virus: origin and relationship with hosts. Australasian Plant Pathol 44:31-41. https://doi.org/1007/s13313-014-0308-5

6. Costa AP, Nogueira I, Peixoto JR, Blum LEB (2020) Screening of sour passion fruit for reaction to bacterial spot and passion fruit woodiness disease. J Agr Scic 12(2):130-137. https://doi/10.5539/jas.v12n2p130

7. Preisigke SDC, Viana AP, Santos EA, Santos PRD, Santos VOD, Ambrósio M, Walter FHDB (2020) Selection strategies in a segregating passion fruit population aided by classic and molecular techniques. Bragantia 79:47-61. http://dx.doi.org/10.1590/1678-4499.20190291

8. Wylie SJ, Jones MG (2011) The complete genome sequence of a Passion fruit woodiness virus isolate from Australia determined using deep sequencing, and its relationship to other potyviruses. Arch Virol 156:479-482. https://doi.org/10.1007/s00705-010-0845-3

9. Wylie SJ, Adams M, Chalam C, Kreuze J, López-Moya JJ, Ohshima K, Zerbini FM (2017) ICTV virus taxonomy profile: Potyviridae. The J gen virol, 98(3):352. https://doi.org/1099/jgv.0.000740 
10. Fischer IH, Rezende JA (2008) Diseases of passion flower (Passiflora). Pest Tech 2:1-19.

11. Bragard C, Caciagli P, Lemaire O, Lopez-Moya JJ, MacFarlane S, Peters D, Torrance L (2013) Status and prospects of plant virus control through interference with vector transmission. Annu rev phytopathol 51:177-201. https://doi.org/10.1146/annurev-phyto-082712-102346

12. Dáder B, Then C, Berthelot E, Ducousso M, Ng JC, Drucker M (2017) Insect transmission of plant viruses: Multilayered interactions optimize viral propagation. Insect science 24:929-946. https://doi.org/10.1111/1744-7917.12470

13. Nascimento AVS, Santana EN, Braz ASK, Alfenas PF, Pio-Ribeiro G, Andrade GP, Zerbini FM (2006) Cowpea aphid-borne mosaic virus (CABMV) is widespread in passionfruit in Brazil and causes passionfruit woodiness disease. Arch Virol 151:1797-1809. https://doi/1007/s00705-006-0755-6

14. Correa MF, Pinto APC, Rezende JAM, Harakava R, Mendes BMJ (2015) Genetic transformation of sweet passion fruit (Passiflora alata) and reactions of the transgenic plants to Cowpea aphid-borne mosaic virus. Eur J Plant Pathol 143:813-821. https://doi/10.1007/s10658-015-0733-5

15. Rodrigues LK, Chaves ALR, Damatto ER, Eiras M (2016) Epidemiological aspects of the transmission and management of Cowpea aphid-borne mosaic virus in a passion fruit orchard. J Plant Pathol 98:531-539. http://dx.doi.org/10.4454/JPP.V98I3.037

16. Spadotti DMDA, Favara GM, Novaes QS, Mello APOA, Freitas DMS, Edwards Molina JP, Rezende JAM (2019) Long lasting systematic roguing for effective management of CABMV in passion flower orchards through maintenance of separated plants. Plant Pathol 68:1259-1267. https://doi.org/10.1111/ppa.13054

17. Silva FHDL, Viana AP, Santos EA, Freitas JCDO, Rodrigues DL, Amaral Júnior, ATD (2017) Prediction of genetic gains by selection indexes and REML/BLUP methodology in a population of sour passion fruit under recurrent selection. Acta Sci Agron 39:183-190. https://doi/4025/actasciagron.v39i2.32554

18. Santos EA, Viana AP, Barros Walter FH, Oliveira Freitas JC, Ramos HCC, Boechat, MSB (2019) First report of a genetic map and evidence of QTL for resistance to CABMV in a segregating population of Passiflora. Eur J Plant Pathol 155:903-915. https://doi.org/10.1007/s10658-019-01822-y

19. Freitas JCO, Viana AP, Santos EA, Silva FH, Paiva CL, Rodrigues R, Eiras M (2015) Genetic basis of the resistance of a passion fruit segregant population to Cowpea aphid-borne mosaic virus (CABMV). Trop Plant Pathol 40:291-297. https://doi/10.1007/s40858-015-0048-2

20. Freitas JCO, Viana AP, Santos EA, Paiva CL, Silva FHDL, Souza MM (2016) Sour passion fruit breeding: Strategy applied to individual selection in segregating population of Passiflora resistant to Cowpea aphid-born mosaic virus (CABMV). Sci Horti 211:241-247. https://doi.org/10.1016/j.scienta.2016.09.002

21. Maciel SDC, Nakano DH, Rezende JAM, Vieira MLC (2009) Screening of Passiflora species for reaction to Cowpea aphid-borne mosaic virus reveals an immune wild species. Sci Agri 66:414-418. https://doi.org/10.1590/S0103-90162009000300018 
22. Oliveira EJ, Soares TL, Barbosa CDJ, Santos-Filho HP, Jesus ON (2013) Disease severity from passion fruit to identify sources of resistance in field conditions. Rev Bras Frutic 35:485-492. https://doi.org/10.1590/S0100-29452013000200018

23. Sacoman NN, Viana AP, Carvalho VS, Santos EA, Rodrigues R (2018) Resistance to Cowpea aphidborne mosaic virus in in vitro germinated genotypes of Passiflora setacea. Rev Bras Frut 40:1-10. https://doi.org/10.1590/0100-29452017607

24. Gonçalves ZS, Lima LKS, Soares TL, Abreu EFM, Jesus Barbosa C, Cerqueira-Silva CBM, Oliveira EJ (2018) Identification of Passiflora spp. genotypes resistant to Cowpea aphid-borne mosaic virus and leaf anatomical response under controlled conditions. Sci Horti 231:166-178. https://doi.org/10.1016/j.scienta.2017.12.008

25. Santos EA, Viana AP, Oliveira Freitas JC, Silva FHDL, Rodrigues R, Eiras, M (2015) Resistance to Cowpea aphid-borne mosaic virus in species and hybrids of Passiflora: advances for the control of the passion fruit woodiness disease in Brazil. Eur J Plant Pathol 143:85-98. https://doi.org/10.1007/s10658-015-0667-y

26. Porto ACM, Lima Santos M, Oliveira AC (2017) Quality of phytopathometric variables generated from a ranking scale for the CABMV-passionfruit pathosystem. Rev Agro@mbiente 12:58-67. https://doi/18227/1982-8470ragro.v12i1.4247

27. Cerqueira-Silva CBM, Melo JRF, Corrêa RX, Oliveira AC (2012) Selection of pathometric variables to assess resistance and infectivity in the passion fruit woodiness pathosystem. Eur J Plant Pathol 134:489-495. https://doi.org/10.1007/s10658-012-0030-5

28. Gonçalves ZS, Jesus ON, Cerqueira-Silva CBM, Diniz RP, Soares TL, Oliveira EJ (2017) Methodological approaches to assess passion fruit resistance (Passiflora) to passionfruit woodiness disease. Biosci J 33. https://doi.org/10.14393/BJ-v33n6a2017-36619

29. Saponari M, Loconsole G, Liao HH, Jiang B, Savino, V, Yokomi, RK (2013) Validation of highthroughput real time polymerase chain reaction assays for simultaneous detection of invasive citrus pathogens. J Virol Methods, 193:478-486. https://doi.org/10.1016/j.jviromet.2013.07.002

30. Osman F, Hodzic E, Kwon SJ, Wang J, Vidalakis G (2015) Development and validation of a multiplex reverse transcription quantitative PCR (RT-qPCR) assay for the rapid detection of Citrus tristeza virus, Citrus psorosis virus, and Citrus leaf blotch virus. J Virol Methods 220:64-75. https://doi.org/10.1016/j.jviromet.2015.04.013

31. Moura RDS, Coelho Filho MA, Gheyi HR, Jesus OND, Lima LKS, Junghans TG (2018) Overcoming dormancy in stored and recently harvested Passiflora cincinnata seeds. Biosci J 34:1158-1166. https://doi.org/10.14393/BJ-v34n5a2018-39451

32. Novaes QS, Rezende JAM (2003) Selected mild strains of Passion fruit woodiness virus (PWV) fail to protect preimmunized vines in Brazil. Sci Agric 60:699-708. https://doi.org/10.1590/S010390162003000400014

33. Mckinney HH (1923) Influence of soil temperature and moisture on infection of wheat seedlings by Helminthosporium sativum. J Agric Res 26:195-218. 
34. Ferreira CF, Gutierrez DL, Kreuze JF, Iskra-Caruana ML, Chabannes M, Barbosa ACO, Jesus ON (2019) Rapid plant DNA and RNA extraction protocol using a bench drill. Genet Mol Res 18:1-8. http://dx.doi.org/10.4238/gmr18394

35. Fontenele R, Abreu R, Lamas N, Alves-Freitas D, Vidal A, Poppiel R, Varsani A (2018) Passion fruit chlorotic mottle virus: molecular characterization of a new divergent geminivirus in Brazil. Viruses 1691-12 https://doi.org/10.3390/v10040169

36. Hulo C, Castro E, Masson P, Bougueleret L, Bairoch A, Xenarios I, Le Mercier P (2011) ViralZone: a knowledge resource to understand virus diversity. Nucleic Acids Res 39:576582.https://doi/10.1093/nar/gkq901

37. Freitas MS (2013) Patossistema Cowpea aphid-borne mosaic virus (CABMV)/maracujazeiro: titulação 'real time' do patógeno, sistema de classificação de reação genética diferencial de genótipos do hospedeiro e indução de resistência genética. Dissertação, Universidade Estadual do Sudoeste da Bahia, UESB, Jequié - BA.

38. Ruiz-Ruiz S, Moreno P, Guerri J, Ambrós, S (2007) A real-time RT-PCR assay for detection and absolute quantitation of Citrus tristeza virus in different plant tissues. J Virol Methods 145:96-105. https://doi.org/10.1016/j.jviromet.2007.05.011

39. Bustin SA, Benes V, Garson JA, Hellemans J, Huggett J, Kubista M, Vandesompele J (2009) The MIQE Guidelines: Minimum Information for Publication of Quantitative Real-Time PCR Experiments. Clin Chem 55:611-622. https://doi.org/10.1373/clinchem.2008.112797

40. Qiagen (2014) QuantiFast SYBR Green PCR Handbook. For fast, quantitative, real-time 757 PCR and two-step RT-PCR using SYBR Green. 44. Available from: 758 https://www.qiagen.com/us/resources/resourcedetail?id=43137f31-afd9-4916-b53c759c18b0fe505b8\&lang=e $n>$. Accessed: April.20, 2020.

41. Wang J, Zhang Y, Wang J, Liu L, Pang X, Yuan W (2017) Development of a TaqMan-based real-time PCR assay for the specific detection of porcine circovirus 3. J Virol Methods, 248:77-180. https://doi.org/10.1016/j.jviromet.2017.07.007

42. Campbell CL, Madden LV (1990) Introducyion to plant disease epidemiology. New York: John Wiley \& Sons,.p. 532.

43. R Development Core Team (2020). R: A Language and Environment for Statistical Computing. R Foundation for Statistical Computing, Vienna.

44. Gower JC (1971) A general coefficient of similarity and some of its properties. Biometrics 27:857874. https://doi.org/2307/2528823

45. Cruz CD (2013) Genes: a software package for analysis in experimental statistics and quantitative genetics. Acta Sci Agron 35:271-276. https://doi/10.4025/actasciagron.v35i3.21251

46. Tamura K, Peterson D, Peterson N, Stecher G, Nei M, Kumar S (2011) MEGA 5: molecular evolutionary genetics analysis using maximum likelihood, evolutionary distance, and maximum parsimony methods. Mol Biol Evol 28:2731-2739. https://doi.org/10.1093/molbev/msr121 
47. Paula MDS, Fonseca MDN, Boiteux LS, Peixoto JR (2010) Genetic characterization of Passiflora species via resistance genes analog markers. Rev Bras Frutic 32:222-229.

https://doi.org/10.1590/S0100-29452010005000021

48. Sacoman NN, Viana AP, Carvalho VS, Santos EA, Rodrigues R (2018) Resistance to Cowpea aphidborne mosaic virus in in vitro germinated genotypes of Passiflora setacea. Rev Bras Frut 40:1-10. https://doi.org/10.1590/0100-29452017607

49. Soares TL, Jesus ON, Souza EH, Rossi ML, Oliveira EJ (2018a) Comparative pollen morphological analysis in the subgenera Passiflora and Decaloba. An Acad Bras Ciênc 90:2381-2396. https://doi.org/10.1590/0001-3765201720170248

50. Richardo J, Silvério, A (2019) New trends in Passiflora L. pollen grains: morphological/aperture aspects and wall layer considerations. Protoplasma 256:923-939. https://doi.org/10.1007/s00709019-01350-w

51. Soares TL, Jesus ON, Souza EH, Oliveira, EJ (2018b) Floral development stage and its implications for the reproductive success of Passiflora Sci Horti 238:333-342.

https://doi.org/10.1016/j.scienta.2018.04.034

52. Soares TL, Jesus OND, Santos-Serejo JAD, Oliveira EJD (2013) In vitro pollen germination and pollen viability in passion fruit (Passiflora). Rev Bras Frutic 35:1116-1126. https://doi.org/10.1590/S010029452013000400023

53. Coelho MDSE, Andrade Bortoleti KC, Araújo FP, Melo NF (2016b) Cytogenetic characterization of the Passiflora edulis Sims x Passiflora cincinnata Mast. interspecific hybrid and its parents. Euphytica 210:93-104. https://doi/10.1007/s10681-016-1704-4

54. Jesus ON, Soares TL, Oliveira EJ, Santos TCP, Farias DH, Bruckner CH, Novaes QS (2016) Dissimilarity based on morphological characterization and evaluation of pollen viability and in vitro germination in Passiflora hybrids and backcrosses. Acta Hortic 1127:401-408.

http://doi/10.17660/ActaHortic.2016.1127.62

55. Pamponét VCC, Souza MM, Silva GS, Micheli F, Melo CAF, Oliveira SG, Corrêa RX (2019) Low coverage sequencing for repetitive DNA analysis in Passiflora edulis Sims: citogenomic characterization of transposable elements and satellite DNA. BMC genomics 20:262. https://doi.org/10.1186/s12864-019-5576-6

56. Cerqueira-Silva CBM, Moreira CN, Figueira AR, Corrêa RX, Oliveira AC (2008) Detection of a resistance gradient to Passion fruit woodiness virus and selection of 'yellow'passion fruit plants under field conditions. Genet Mol Res 7:1209-1216. https://doi/10.4238/vol7-4gmr484

57. Viana CDS, Pires MDC, Peixoto JR, Junqueira NTV, Blum LEB (2014) Partial resistance of passion fruit genotypes to the virose of the woodiness of the fruit (Cowpea aphid-borne mosaic virusCABMV). Biosci J 30:338-345.

58. Cruz Neto AJ, Rosa RCC, Oliveira EJD, Sampaio SR, Santos ISD, Souza PU, Jesus ON (2016) Genetic parameters, adaptability and stability to selection of yellow passion fruit hybrids. Crop Breed Appl Biotechnol 16:321-329. https://doi.org/10.1590/1984-70332016v16n4a48 
59. Jesus CASD, Carvalho EVD, Girardi EA, Rosa RCC, Jesus ON (2018) Fruit quality and production of yellow and sweet Passion fruits in northern state of São Paulo. Rev Bras Frutic 40:1-7. http://dx.doi.org /10.1590/0100-29452018968

60. Fonseca KG, Faleiro FG, Peixoto JR, Junqueira NTV, Silva MS, Bellon G, FariaVaz C (2009) Recovery analysis of recurrent genitor in sour passion fruit through RAPD markers. Rev Bras Frutic 31:145-153. https://doi.org/10.1590/S0100-29452009000100021

61. Suassuna TMF, Bruckner CH, Carvalho CR, Borém, A (2003) Self-incompatibility in passionfruit: evidence of gametophytic-sporophytic control. Theor Appl Genet 106:298-302. https://doi/10.1007/s00122-002-1103-1

62. Madureira HC, Pereira TNS, Cunha MD, Klein DE (2012) Histological analysis of pollen-pistil interactions in sour passion fruit plants (Passiflora edulis Sims). Biocell 36:83-90.

63. Obrępalska-Stęplowska A, Renaut J, Planchon S, Przybylska A, Wieczorek P, Barylski J, Palukaitis P (2015) Effect of temperature on the pathogenesis, accumulation of viral and satellite RNAs and on plant proteome in peanut stunt virus and satellite RNA-infected plants. Front Plant Sci 6:903. https://doi/10.3389/fpls.2015.00903

64. Pinto PHD, Peixoto JR, Junqueira NTV, Resende RDO, Mattos JKDA, Melo BD (2008) Reaction of passionfruit genotypes to Cowpea aphid-borne mosaic virus (cabmv). Biosci J 24:19-26.

65. Nicolini C, Rabelo Filho FA, Resende RO, Andrade GP, Kitajima EW, Pio Ribeiro G, Nagata T (2012) Possible Host Adaptation as an Evolution Factor of Cowpea aphid-borne mosaic virus Deduced by Coat Protein Gene Analysis. J Phytopathol 160:82-87. https://doi:/10.1111/j.14390434.2011.01861.x

66. Vidal AH, Sanches MM, Alves-Freitas DMT, Abreu EF, Lacorte C, Pinheiro-Lima B, Ribeiro SG (2018) First World Report of Cucurbit aphid-borne yellows virus infecting Passion fruit. Plant Dis 102:26652665. https://doi.org/10.1094/PDIS-04-18-0694-PDN

67. Garcêz RM, Chaves ALR, Eiras M, Meletti LMM, Azevedo Filho JA, Silva LA, Colariccio A (2015) Survey of aphid population in a yellow passion fruit crop and its relationship on the spread Cowpea aphid-borne mosaic virus in a subtropical region of Brazil. Springer Plus 537:1-12. https://doi.org/10.1186/s40064-015-1263-5

68. Roossinck MJ, Martin DP, Roumagnac $P$ (2015) Plant virus metagenomics: advances in virus discovery. Phytopathology 105: 716-727. https://doi.org/10.1094/PHYTO-12-14-0356-RVW

69. Sun SR, Ahmad K, Wu XB, Chen JS, Fu HY, Huang MT, Gao SJ (2018) Development of quantitative real-time PCR assays for rapid and sensitive detection of two badnavirus species in sugarcane. Biomed Res Int 1-10. https://doi.org/10.1155/2018/8678242

70. Novaes QS, Rezende JA (2005) Protection between strains of Passion fruit woodiness virus in sunnhemp. Fitopatol Bras 30:307-311. http://dx.doi.org/10.1590/S0100-41582005000300017

71. Giampan JS, Rezende JAM (2005) The effect of different variables on the infectivity of mild strains of Papaya ringspot virus in watermelon plants. Fitopatol Bras 30:39-45.

https://doi.org/10.1590/S0100-41582005000100007

Page 26/39 
72. Freitas DMS, Rezende JAM (2008) Protection between strains of Papaya ringspot virus: Type W in zucchini squash involves competition for viral replication sites. Sci Agric 65:183-189.

http://dx.doi.org/10.1590/S0103-90162008000200012

73. Liu J, Li XD, Xu S (2020) Single amino acid substitutions in the coat protein and RNA-dependent RNA polymerase alleviated the virulence of Cucumber green mottle mosaic virus and conferred cross protection against severe infection. Virus Genes 1-8. https://doi.org/10.1007/s11262-019-01726-3

74. Huang XD, Fang L, Gu QS, Tian YP, Geng C, Li XD (2019) Cross protection against the watermelon strain of Papaya ringspot virus through modification of viral RNA silencing suppressor. Virus res 265:166-171. https://doi.org/10.1016/j.virusres.2019.03.016

75. Folimonova SY (2012) Superinfection exclusion is an active virus-controlled function that requires a specific viral protein. J Virol 86:5554-5561. https://doi/1128/JVI.00310-12

76. Lin CY, Tsai WS, Ku HM, Jan F (2012) Evaluation of DNA fragments covering the entire genome of a monopartite begomovirus for induction of viral resistance in transgenic plants via gene silencing. Transgenic res 21:231-241. https://doi.org/10.1007/s11248-011-9523-9

77. Kumar S, Tanti B, Patil BL, Mukherjee SK, Sahoo L (2017) RNAi-derived transgenic resistance to Mungbean yellow mosaic India virus in cowpea. PloS One 12:1-20. https://doi.org/10.1371/journal.pone.0186786

78. Deng Y, Wang J, Tung J, Liu D, Zhou Y, He S, Li F (2018) A role for small RNA in regulating innate immunity during plant growth. PLoS pathog 14:1-22. https://doi.org/10.1371/journal.ppat.1006756

79. Sunitha S, Shanmugapriya G, Balamani V, Veluthambi K (2013) Mungbean yellow mosaic virus (MYMV) AC4 suppresses post-transcriptional gene silencing and an AC4 hairpin RNA gene reduces MYMV DNA accumulation in transgenic tobacco. Virus genes 46:496-504. http://doi/10.1007/s11262-013-0889-z

80. Csorba T, Kontra L, Burgyán J (2015) Viral silencing suppressors: tools forged to fine-tune hostpathogen coexistence. Virology 479:85-103. https://doi.org/10.1016/j.virol.2015.02.028

81. Lucho SR, Amaral MN, Benitez LC, Milech C, Kleinowski AM, Bianchi VJ, Braga EJB (2018) Validation of reference genes for RT-qPCR studies in Stevia rebaudiana in response to elicitor agents. Physiol mol biol plants 24:767-779. https://doi.org/10.1007/s12298-018-0583-7

82. Fajardo TVM, Vanni MF, Nickel O (2017) Absolute quantification of viruses by TaqMan real-time RTPCR in grapevines. Ciênc Rural 47:1-5. https://doi.org/10.1590/0103-8478cr20161063

83. Ruiz-Ruiz S, Moreno P, Guerri J, Ambros S (2009) Discrimination between mild and severe Citrus tristeza virus isolates with a rapid and highly specific real-time reverse transcription-polymerase chain reaction method using TaqMan LNA probes. Phytopathology 99:307-315. https://doi.org/10.1094/PHYTO-99-3-0307

84. Ferriol I, Ruiz-Ruiz S, Rubio L (2011) Detection and absolute quantitation of Broad bean wilt virus 1 (BBWV-1) and BBWV-2 by real time RT-PCR. J Virol Methods 177:202-205. https://doi.org/10.1016/j.jviromet.2011.08.003 
85. Herrera-Vásquez JA, Rubio L, Alfaro-Fernández A, Debreczeni DE, Font-San-Ambrosio I, Falk BW, Ferriol I (2015) Detection and absolute quantitation of Tomato torrado virus (ToTV) by real time RTPCR. J Virol Methods 221:90-94. http://dx.doi.org/10.1016/j.jviromet.2015.04.029

86. Dai M, Feng M, Liu D, Cao W, Liao M (2015) Development and application of SYBR Green I real-time PCR assay for the separate detection of subgroup J Avian leukosis virus and multiplex detection of avian leukosis virus subgroups A and B. Virol J 12:52. http://doi/10.1186/s12985-015-0291-7

87. Cooper Jl, Jones AT (1983) Responses of plants to viruses: proposals for the use of terms. Phytopathology, 73:127-128.

88. Doumayrou J, Leblaye S, Froissart R, Michalakis Y (2013) Reduction of leaf area and symptom severity as proxies of disease-induced plant mortality: The example of the Cauliflower mosaic virus infecting two Brassicaceae hosts. Virus Res 176:91-100.

https://doi.org/10.1016/j.virusres.2013.05.008

89. Paudel DB, Sanfaçon H (2018) Exploring the diversity of mechanisms associated with plant tolerance to virus infection. Front Plant Sci 9:1575. https://doi.org/10.3389/fpls.2018.01575

90. Pagán I, García-Arenal F (2018) Tolerance to plant pathogens: Theory and experimental evidence. Int J Mol Sci 19:810. https://doi.org/10.3390/ijms19030810

91. Dangl JL, Horvath DM, Staskawicz BJ (2013) Pivoting the plant immune system from dissection to deployment. Science 341:746-751. http://doi/10.1126/science.1236011

92. Bigeard J, Colcombet J, Hirt H (2015) Signaling mechanisms in pattern-triggered immunity (PTI). Molecular plant 8:521-539. http://dx.doi.org/10.1016/j.molp.2014.12.022

93. Niehl A, Wyrsch I, Boller T, Heinlein M (2016) Double stranded RNA s induce a pattern triggered immune signaling pathway in plants. New Phytol, 211:1008-1019.

https://doi.org/10.1111/nph.13944

94. Cui J, You C, Chen X (2017) The evolution of microRNAs in plants. Curr Opin Plant Biol 35:61-67. https://doi.org/10.1016/j.pbi.2016.11.006

95. Wang S, Cui W, Wu X, Yuan Q, Zhao J, Zheng H, Yan F (2018) Suppression of nbe miR166h p5 attenuates leaf yellowing symptoms of potato virus $X$ on Nicotiana benthamiana and reduces virus accumulation. Mol plant pathol 19:2384-2396. https://doi.org/10.1111/mpp.12717

96. Gouveia BC, Calil IP, Machado JPB, Santos AA, Fontes EP (2017) Immune receptors and co-receptors in antiviral innate immunity in plants. Front Microbiol 2139:1-14. https://doi.org/10.3389/fmicb.2016.02139

97. Patil BL, Ogwok E, Wagaba H, Mohammed IU, Yadav JS, Bagewadi B, Fauquet CM (2011) RNAi mediated resistance to diverse isolates belonging to two virus species involved in Cassava brown streak disease. Mol Plant Pathol 12:31-41. https://doi.org/10.1111/j.1364-3703.2010.00650.x

98. Cruz ARR, Aragão FJL (2014) RNAi based enhanced resistance to Cowpea severe mosaic virus and Cowpea aphid borne mosaic virus in transgenic cowpea. Plant pathol 63:831-837. https://doi.org/10.1111/ppa.12178 
99. Chirinos DT, Geraud-Pouey F, Fernandez CE, Bragard C, Romay G (2020) Genomic characterization and transmission efficiency by its vector Bemisia tabaci of a novel recombinant strain of potato yellow mosaic virus. Trop Plant Pathol 45:91-95. https://doi.org/10.1007/s40858-019-00316-w

100. Kondo H, Fujita M, Hisano H, Hyodo K, Andika IB, Suzuki N (2020) Virome analysis of aphid populations that infest the barley field: the discovery of two novel groups of nege/kita-like viruses and other novel RNA viruses. Front Microbiol 11:1-19. https://doi.org/10.3389/fmicb.2020.00509

101. Carvalho BM, Viana AP, Santos PHD, Generoso AL, Corrêa CCG, Silveira V, Santos EA (2019) Proteome of resistant and susceptible Passiflora species in the interaction with cowpea aphid-borne mosaic virus reveals distinct responses to pathogenesis. Euphytica 215:167. https://doi.org/10.1007/s10681-019-2491-5

\section{Figures}

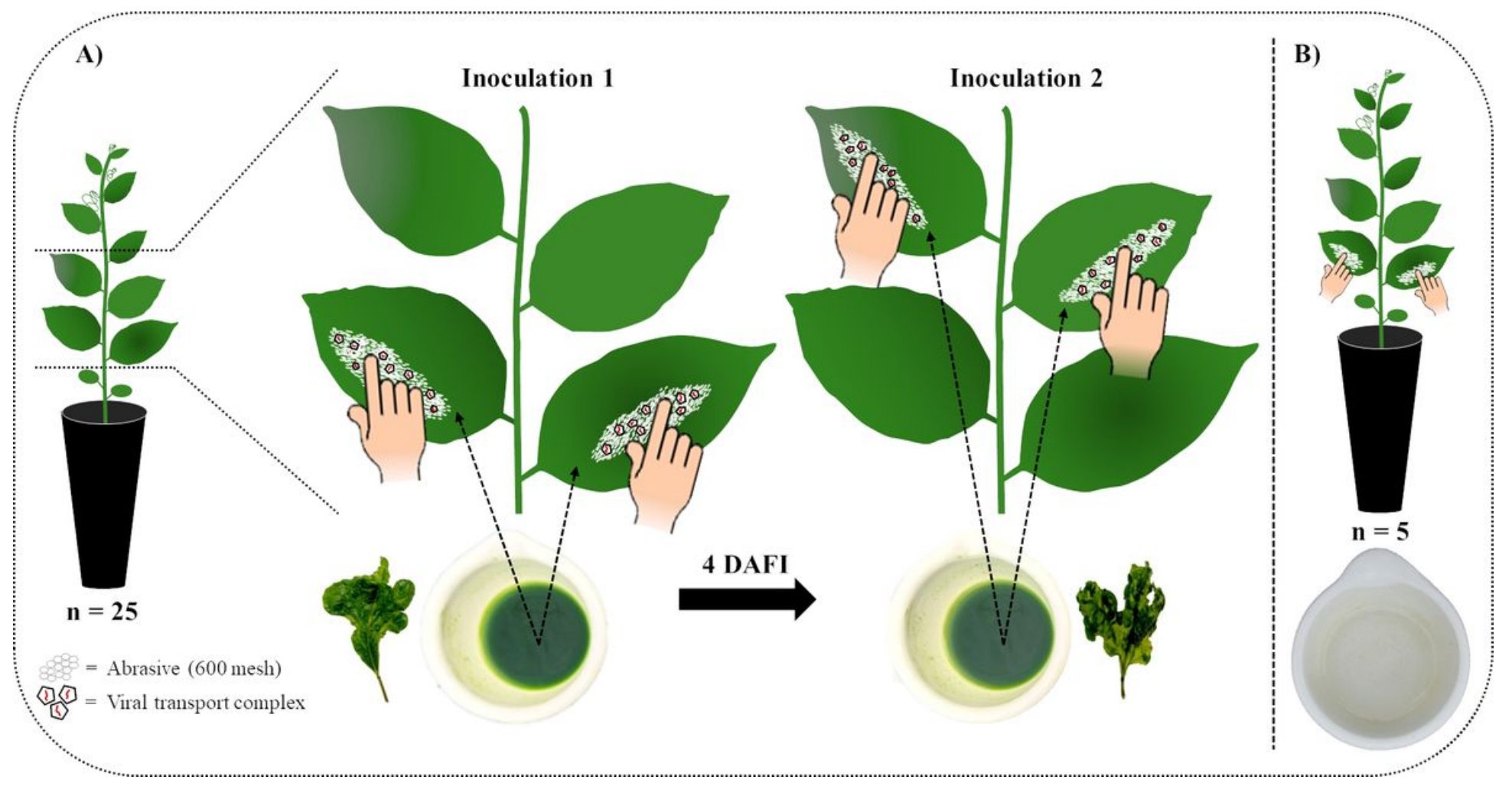

Figure 1

Artificial inoculations scheme with the passion fruit woodiness disease (Cowpea aphid-borne mosaic virus - CABMV) in the 128 Passiflora spp. genotypes. A) inoculation performed from the leaf extract preparation with viruses symptoms and cellite; B) inoculation with buffer and abrasive in plants used as control (negative control). DAFI: Days after the first inoculation. 


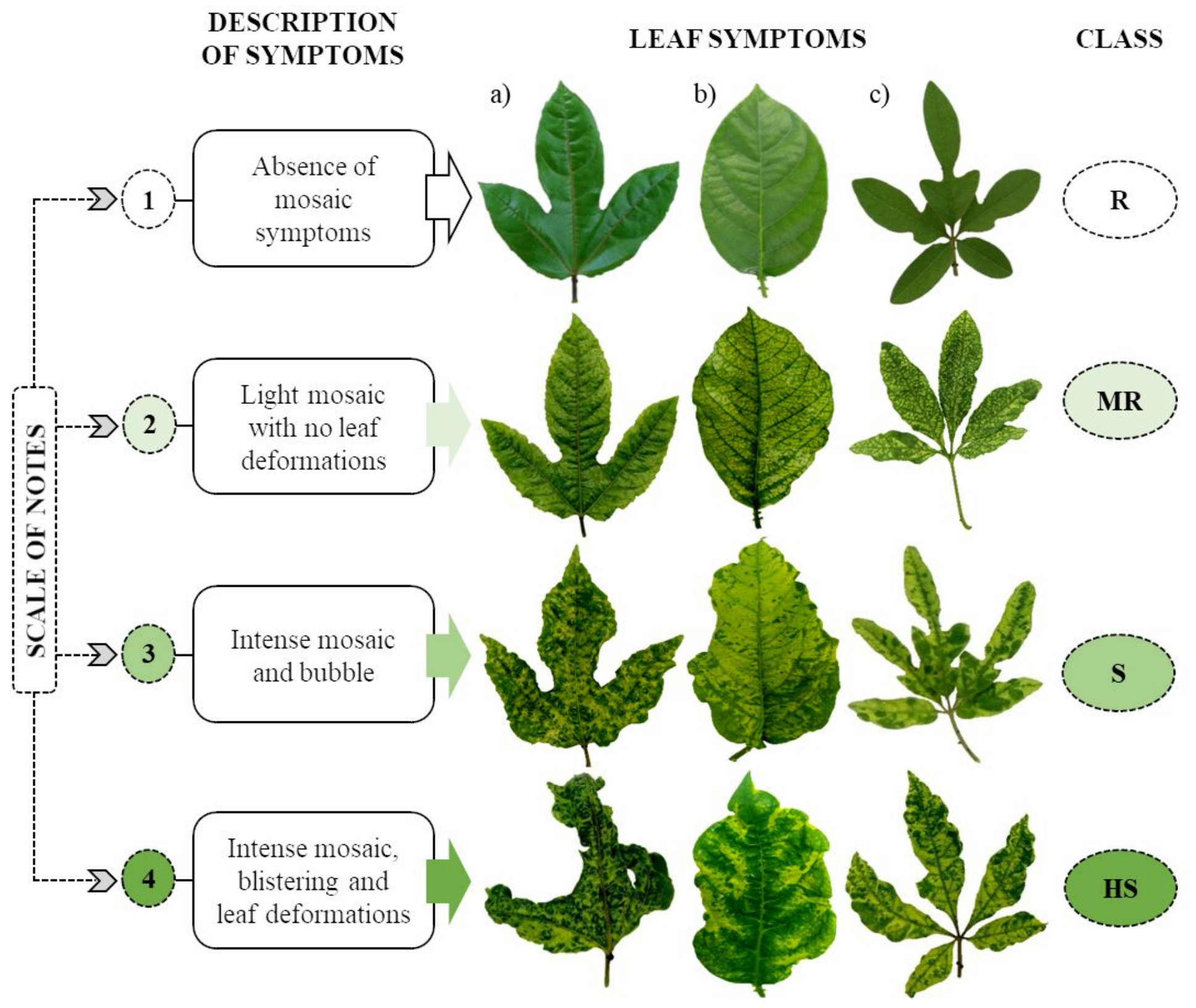

Figure 2

Grade scale (1 to 4), description of the leaf symptoms observed in Passiflora edulis (a), P. alata (b) and P. cincinnata (c) plants inoculated with CABMV (Cowpea aphid-borne mosaic virus) and phenotypic class associated with each gradient of leaf symptoms. $\mathrm{R}=$ resistant; $\mathrm{MR}=$ moderately resistant; $\mathrm{S}=$ susceptible and $\mathrm{HS}=$ highly susceptible. 


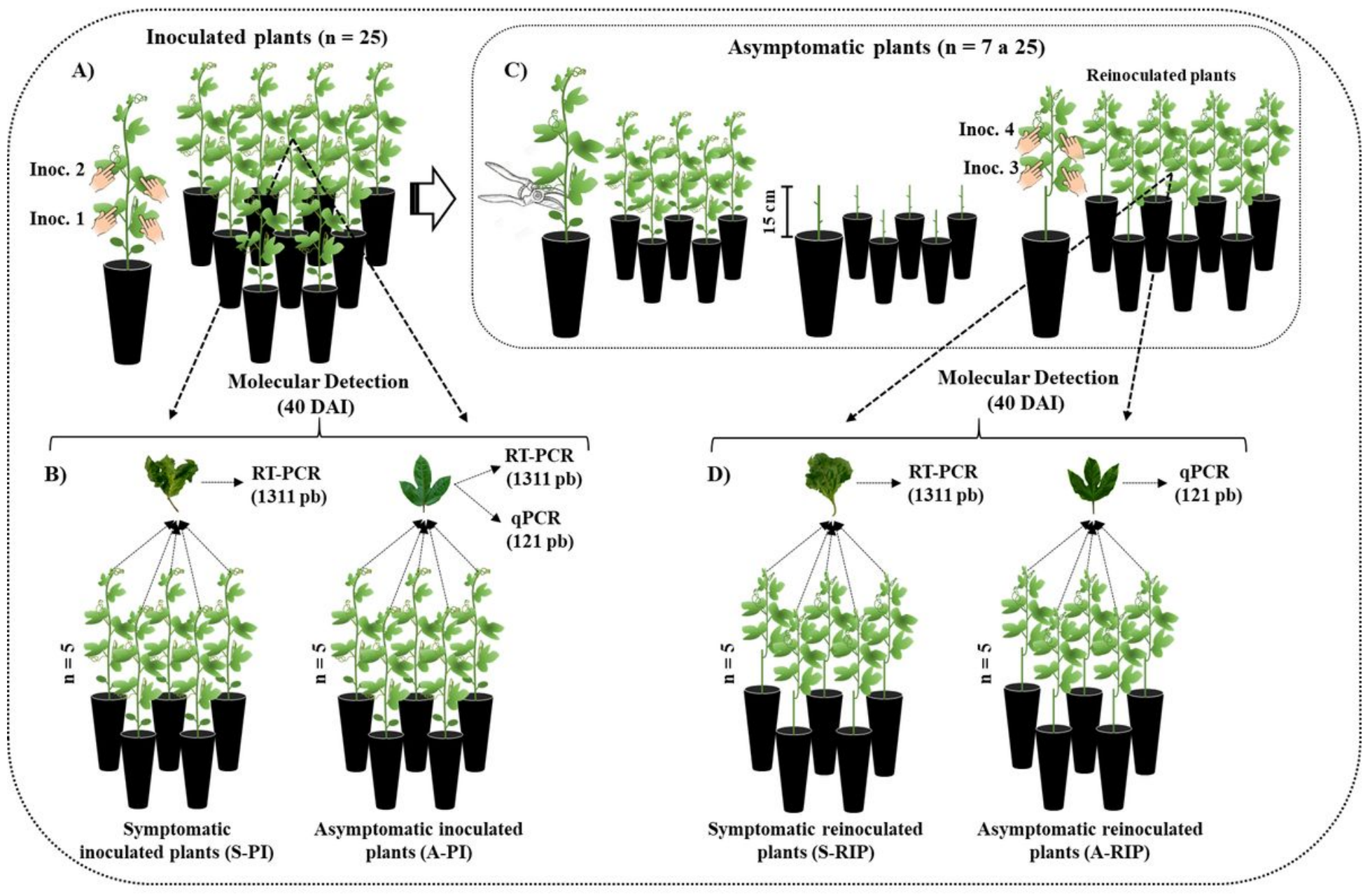

Figure 3

Representative scheme of the steps for the detection of CABMV infection in symptomatic and asymptomatic inoculated plants. A) inoculations ( 1 and 2 ) and evaluations of viruses symptoms in passion fruit plants; B) apical leaf tissue collection of plants inoculated with and without symptoms after $40 \mathrm{DAl} ; \mathrm{C}$ ) separation of plants that did not present symptoms, pruning and reinoculation (inoculation 3 and 4) of plants after 40 DAP; D) apical leaf tissue collection of symptomatic and asymptomatic reinoculated plants after $40 \mathrm{DAI}$ for CABMV amplification test through RT-PCR and qPCR. Inoc. = Inoculation; DAI = Days after inoculation; RT-PCR = Reverse Transcriptase - Polymerase Chain Reaction; qPCR $=$ Real Time quantitative Polymerase Chain Reaction.

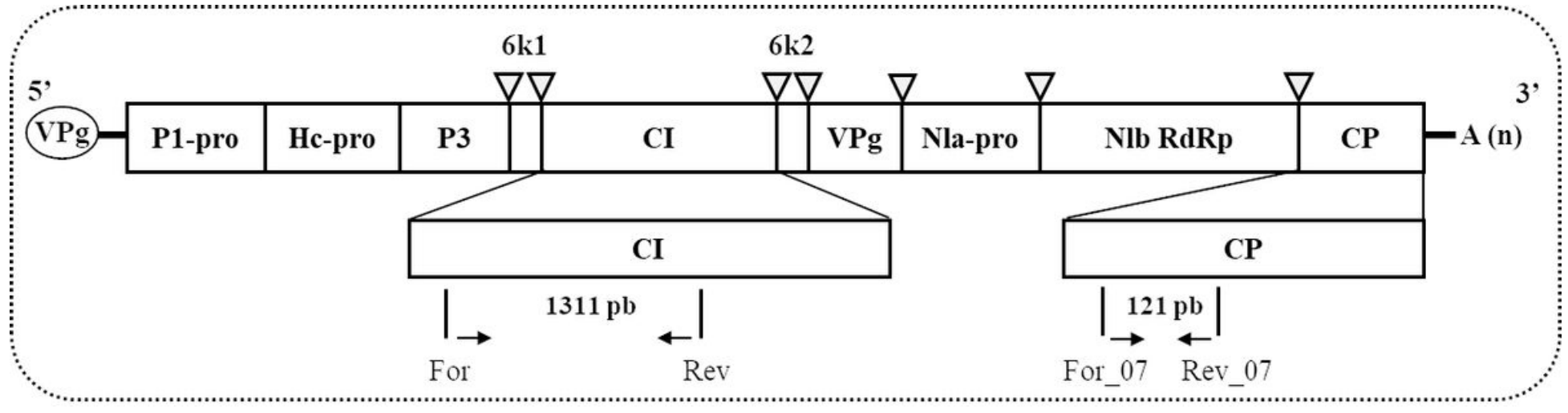




\section{Figure 4}

Schematic design of the annealing position of the two primer pairs used in the RT-PCR and qPCR reactions to amplify the gene portion of the cylindrical inclusion $(\mathrm{Cl})$ and coat protein $(\mathrm{CP})$ of Cowpea aphid-borne mosaic virus (CABMV). For = Forward; Rev = Reverse. The scheme of the Potyvirus genome organization illustrated above was adapted from ViralZone@ [36]. Available at: www.expasy.org/viralzone.

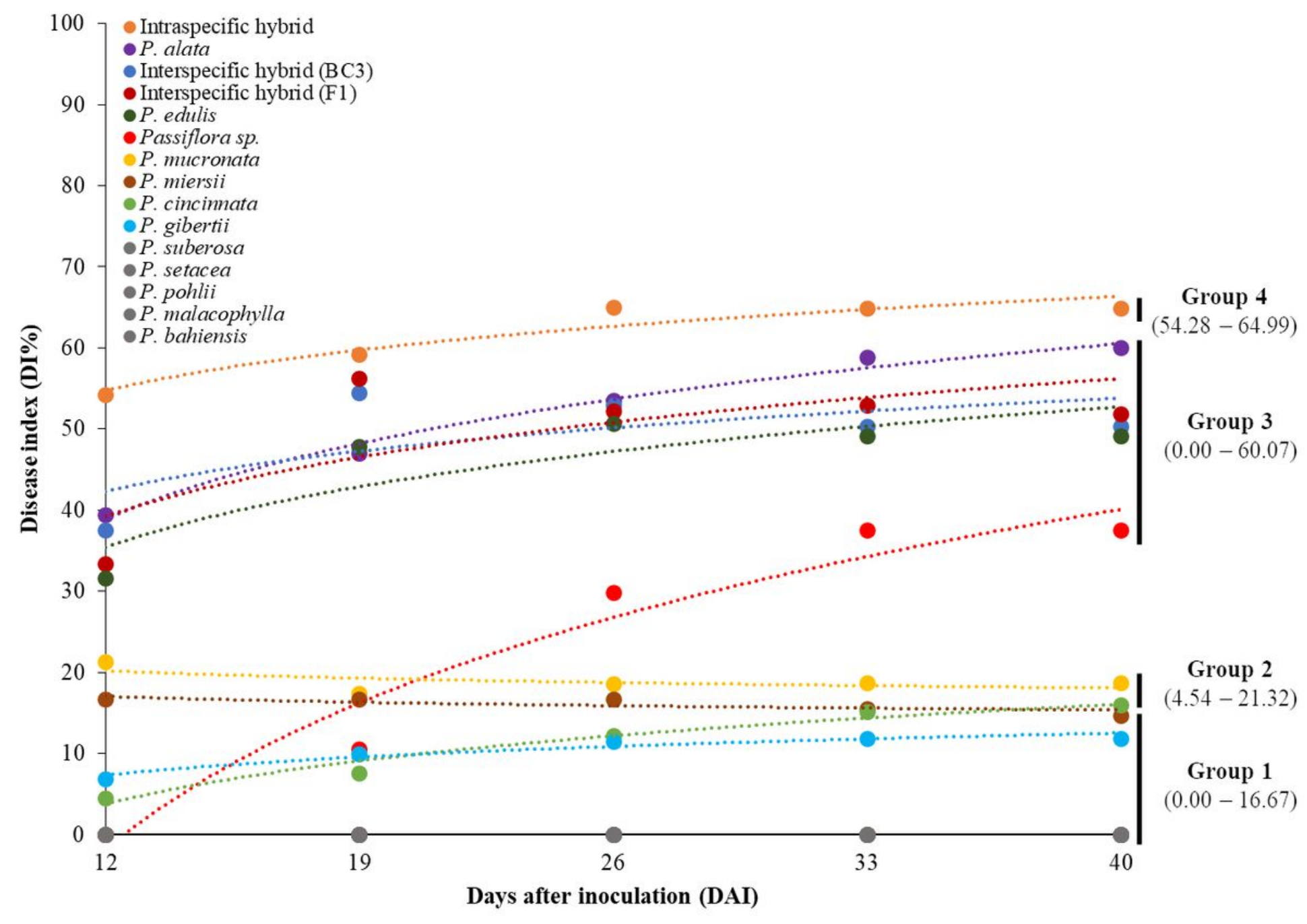

\section{Figure 5}

Logarithmic regression for the disease index (DI \%) in 12 species of Passiflora spp. and three hybrids (inter and intraspecific) in different periods after inoculation (DAl) with the passion fruit woodiness disease (Cowpea aphid-borne mosaic virus - CABMV). Group 1 (resistant - R: P. suberosa, P. setacea, P. pohlii, P. malacophylla, P. bahiensis, P. gibertii and P. miersii); Group 2 (moderately resistant - MR: P. mucronata and P. cincinnata); Group 3 (susceptible - S: P. alata, Interspecific hybrids BC3 and F1, P. edulis and Passiflora sp.); Group 4 (highly susceptible - HS: Intraspecific hybrid). The values in brackets represent the amplitude of the disease index (DI \%) of the species that compound each group. 

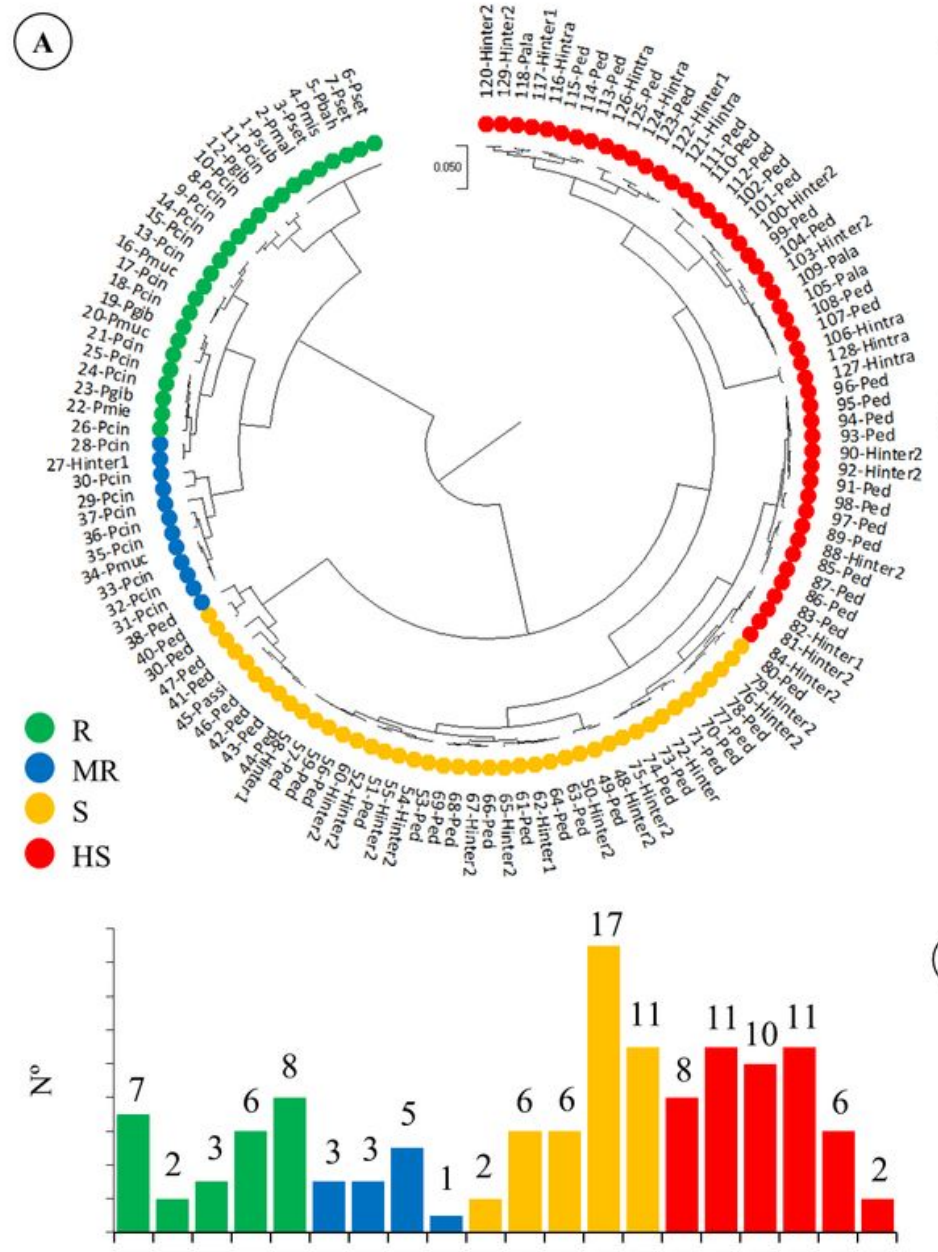

हбन ปที

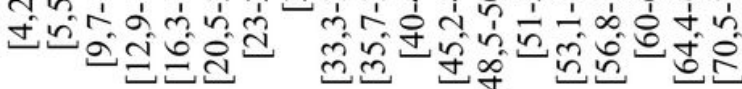
Class

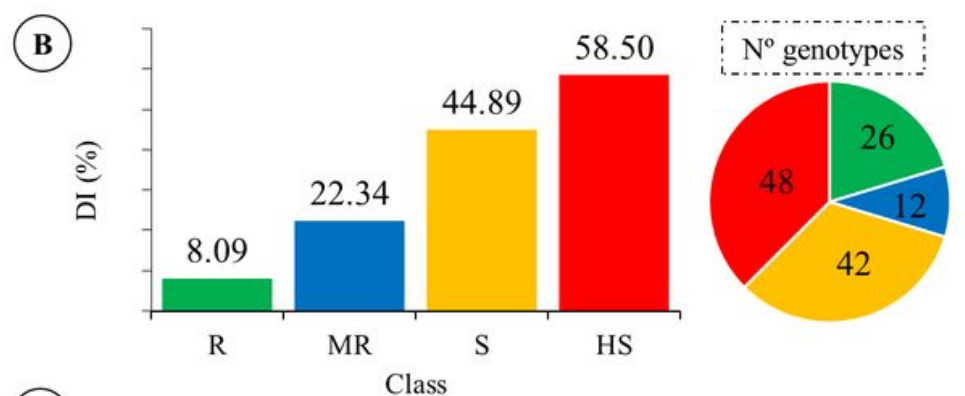

(C)
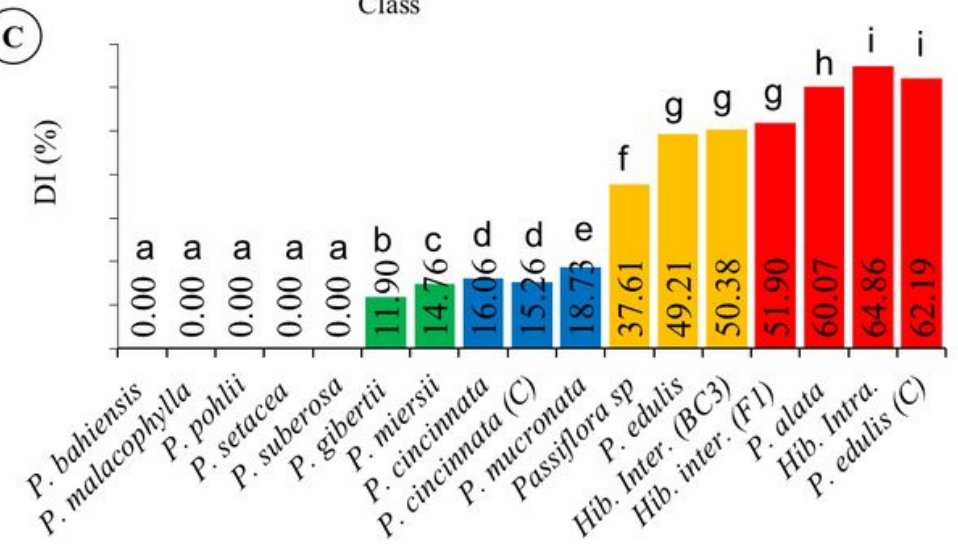

(D)

Species
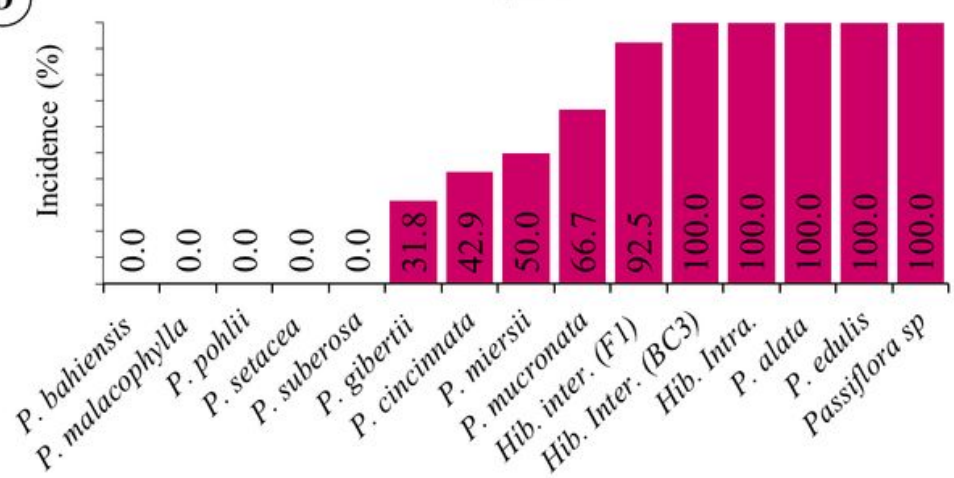

Species

Figure 6

Cluster and severity values (DI\%) in 128 genotypes of Passiflora spp. (A); mean values and number of genotypes in the resistant classes (R), moderately resistant (MR), susceptible (S) and highly susceptible (HS) (B) and mean values and their distribution in the classes R, MR, S and HS of the 12 species of Passiflora spp., an intraspecific hybrid, a simple interspecific hybrid (F1) and an interspecific hybrid of the third generation of backcrossing [BC3 - (P. edulis $\times$ P. cincinnata) $\times$ P. edulis)] and incidence of viruses in the species (D). 


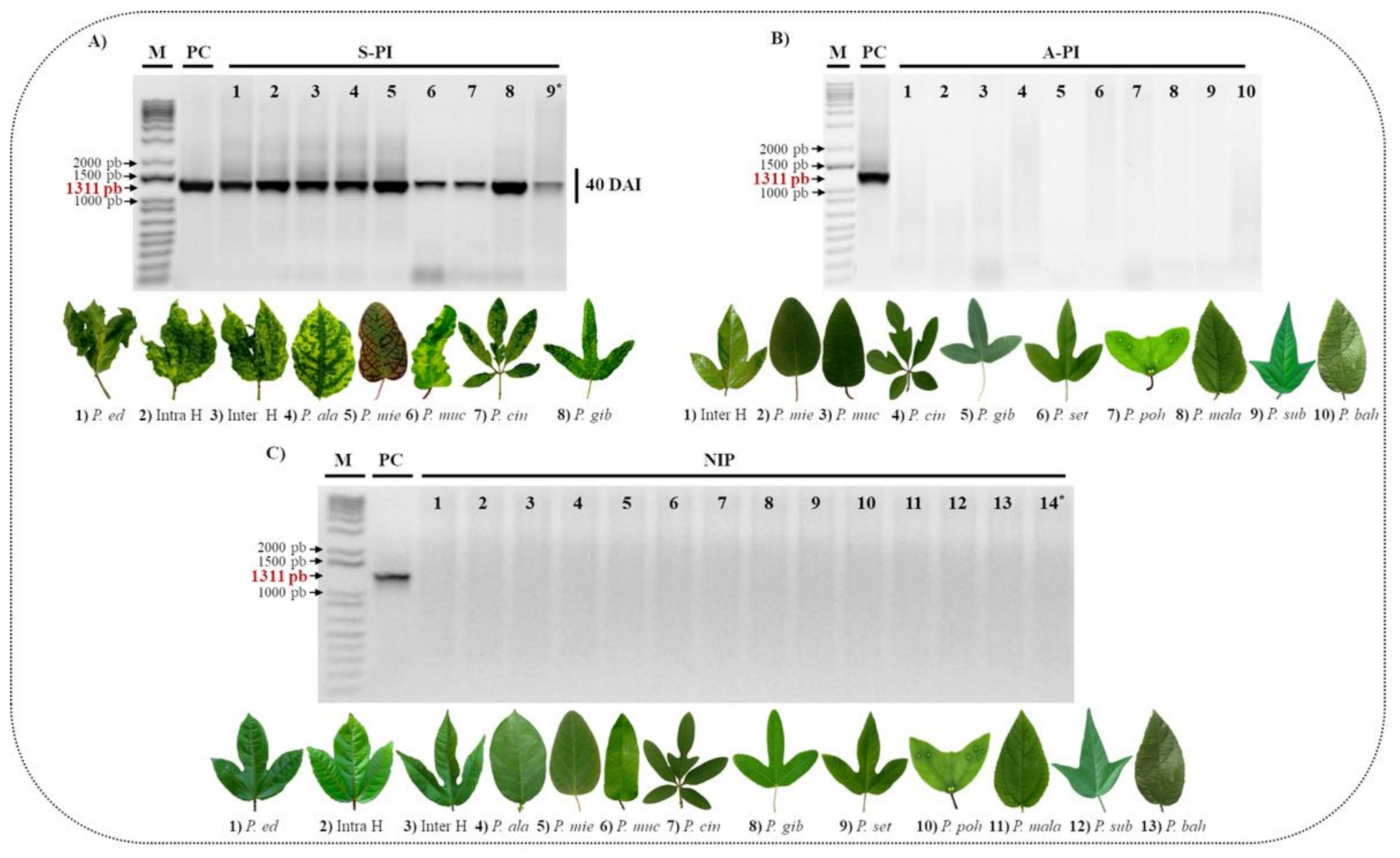

Figure 7

Products of amplification by RT-PCR in agarose gel $1 \%$ using primers for the genomic fragment of the cylindrical inclusion of CABMV (Cowpea aphid-borne mosaic virus) of $1311 \mathrm{pb}$. A) pool of leaf samples of symptomatic inoculated plants (S-IP) at 40 days after inoculated (DAI); B) pool of leaf samples of asymptomatic inoculated plants (A-IP); C) pool of leaf samples of not inoculated plants with CABMV (NIP, negative controls). PC: Positive control (Matrices plants of P. edulis with CABMV symptoms - cDNA 200 ng. $\mu \mathrm{L}-1) . \mathrm{M}=$ Molecular DNA Marker Ladder of $1 \mathrm{~Kb}\left(\right.$ Invitrogen $\left.^{\mathrm{TM}}\right)$. P. ed = Passiflora edulis; Intra $\mathrm{H} .=$ Intraspecific Hybrid; Inter H. = Interspecific Hybrid; P. ala = P. alata; P. mie = P. miersii; P. muc = P.

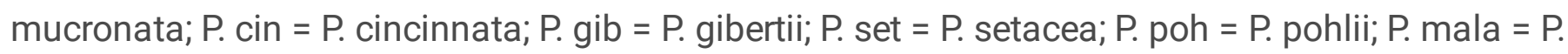
malacophylla; P. sub = P. suberosa; P. bah = P. bahiensis. *Unregistered leaf tissue (Passiflora sp BGP482). 

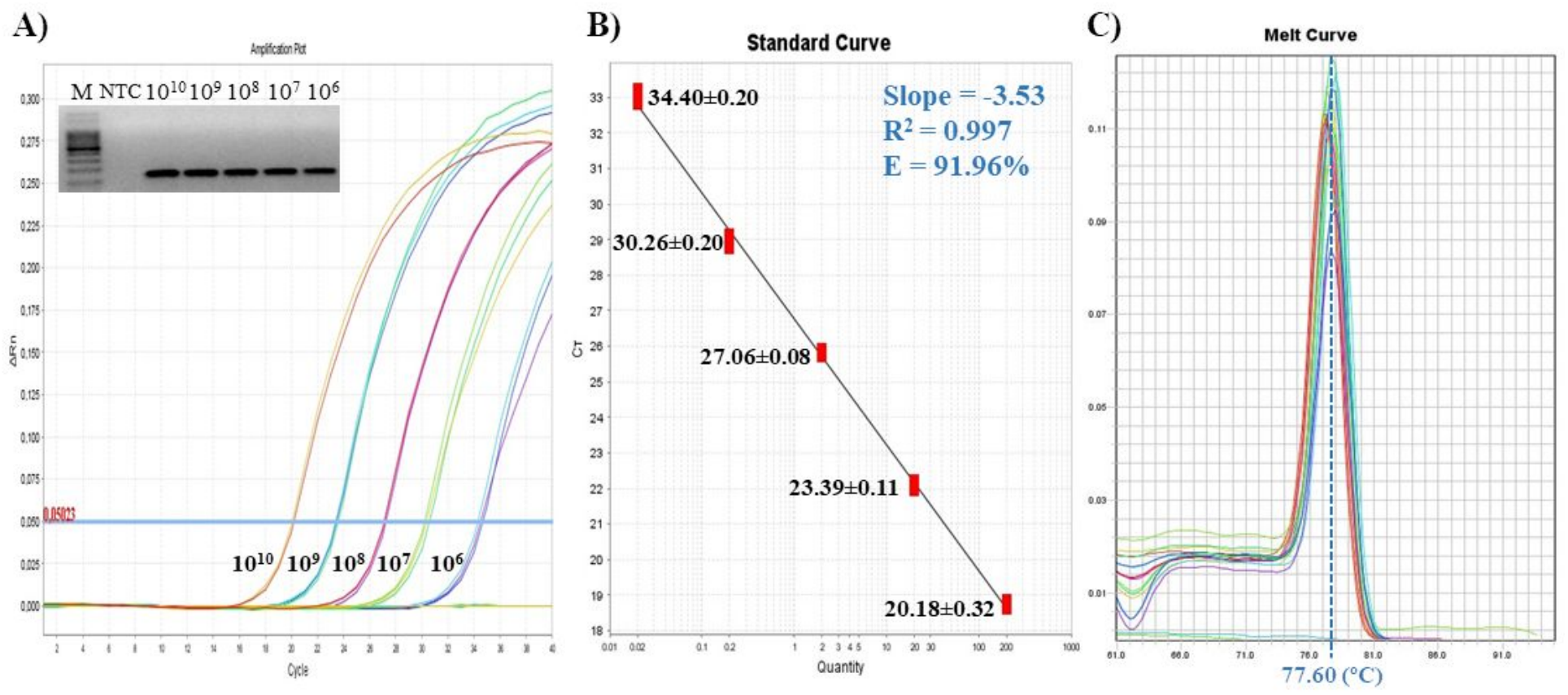

\section{Figure 8}

Quantitative real-time PCR (qPCR) of the serial dilutions for amplification efficiency of the primer qCABMV07. A) Graphic of amplifications obtained from the serial dilutions of cDNA (200 ng. $\mu \mathrm{L}-1)$; B) Curve of the serial dilutions of CDNA and quality and precision parameters of amplification of the primer qCABMV07 in qPCR; $C$ ) Dissociation curves (Curve melting) of the serial dilutions. $M=$ Molecular DNA Marker Ladder of 100 pb (Ludwig $\left.{ }^{\circledR}\right)$; NTC (Non Template Control) = without mold cDNA. The numbers on the left side of the curve represent the mean values of the $\mathrm{Ct}$ of the technical replicates of each point of the serial dilution and the standard deviation of the $\mathrm{Ct}$. 


\section{Standard Curve}

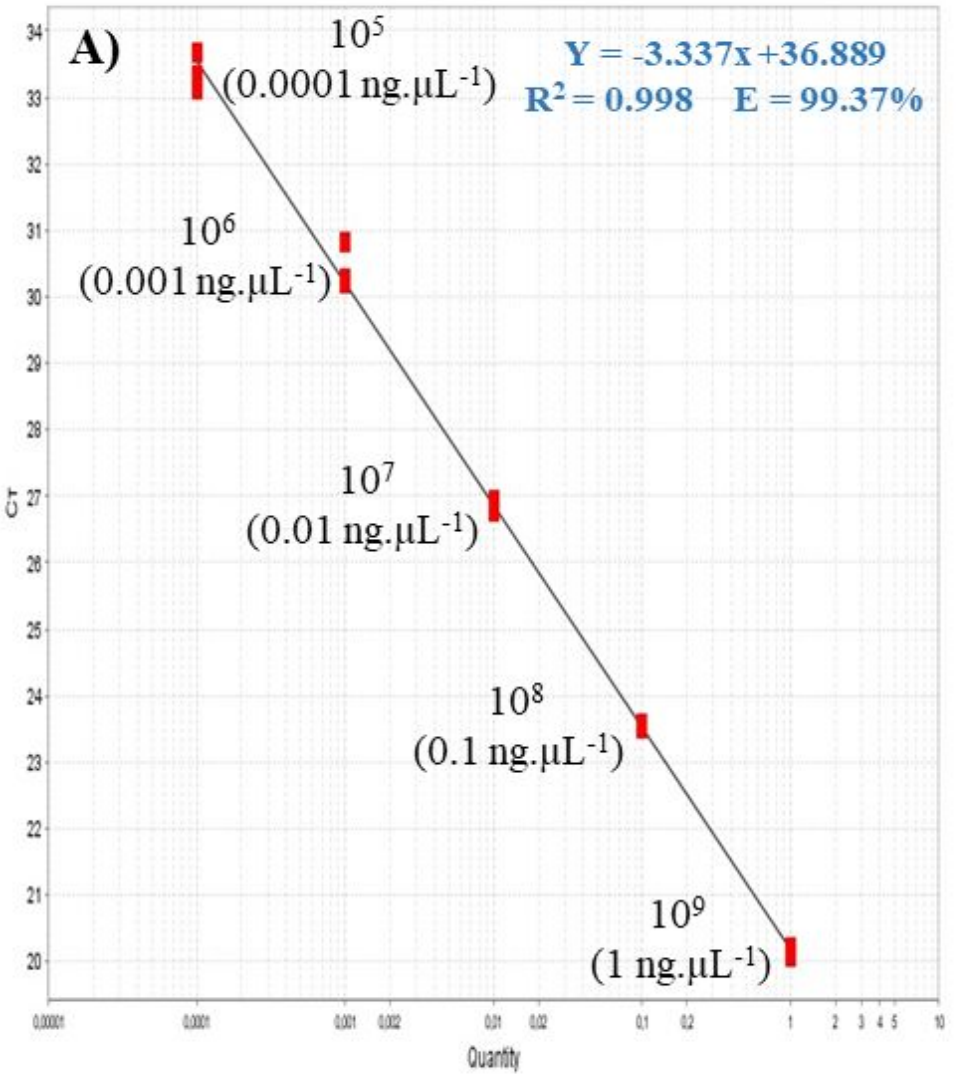

Melt Curve

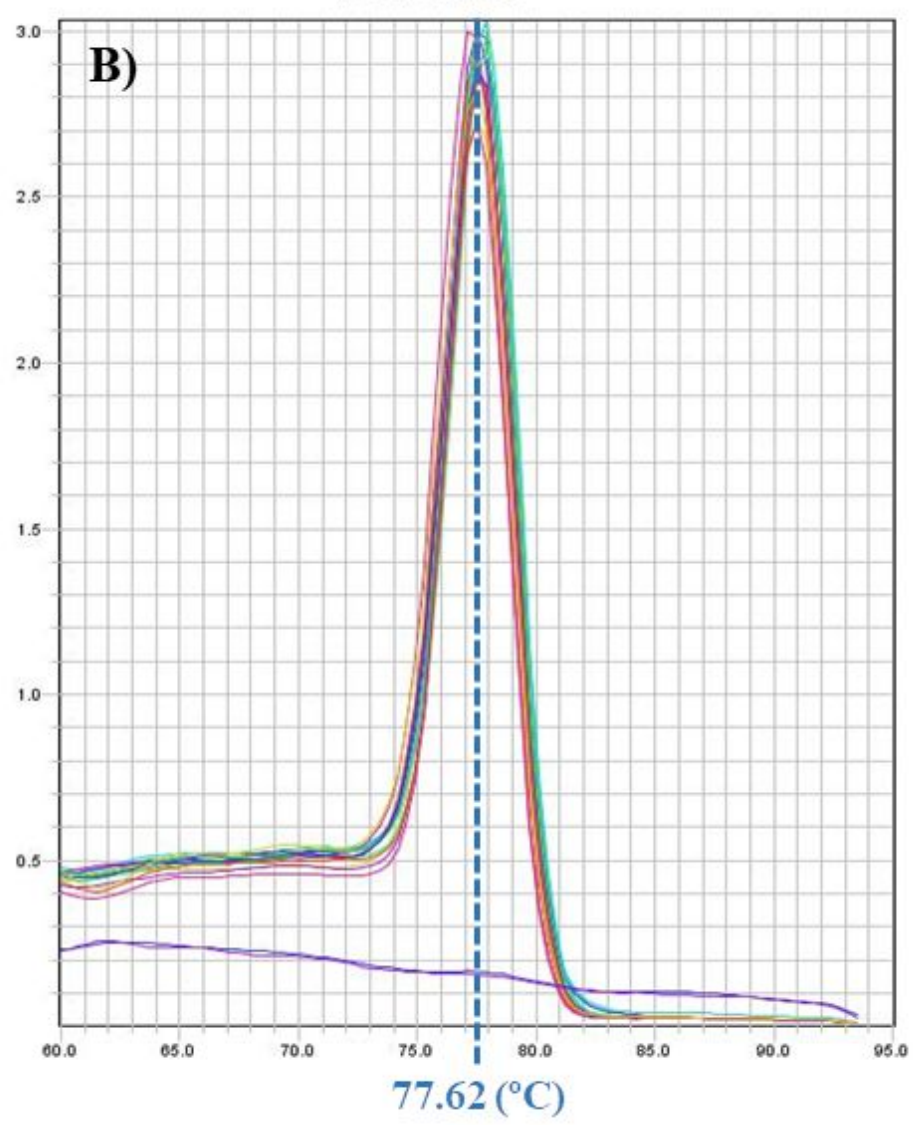

Figure 9

A) Standard curve of serial dilutions at 10 times (1:10) and quality and accuracy parameters of the qPCR reaction of part of the CABMV coat protein gene with primer qCABMV07; B) Dissociation curves (Melting curve) of the amplifications of the serial dilutions. The values on the left side of the standard curve represent the concentrations (ng. $\mathrm{LL}-1$ ) of each serial dilution. 


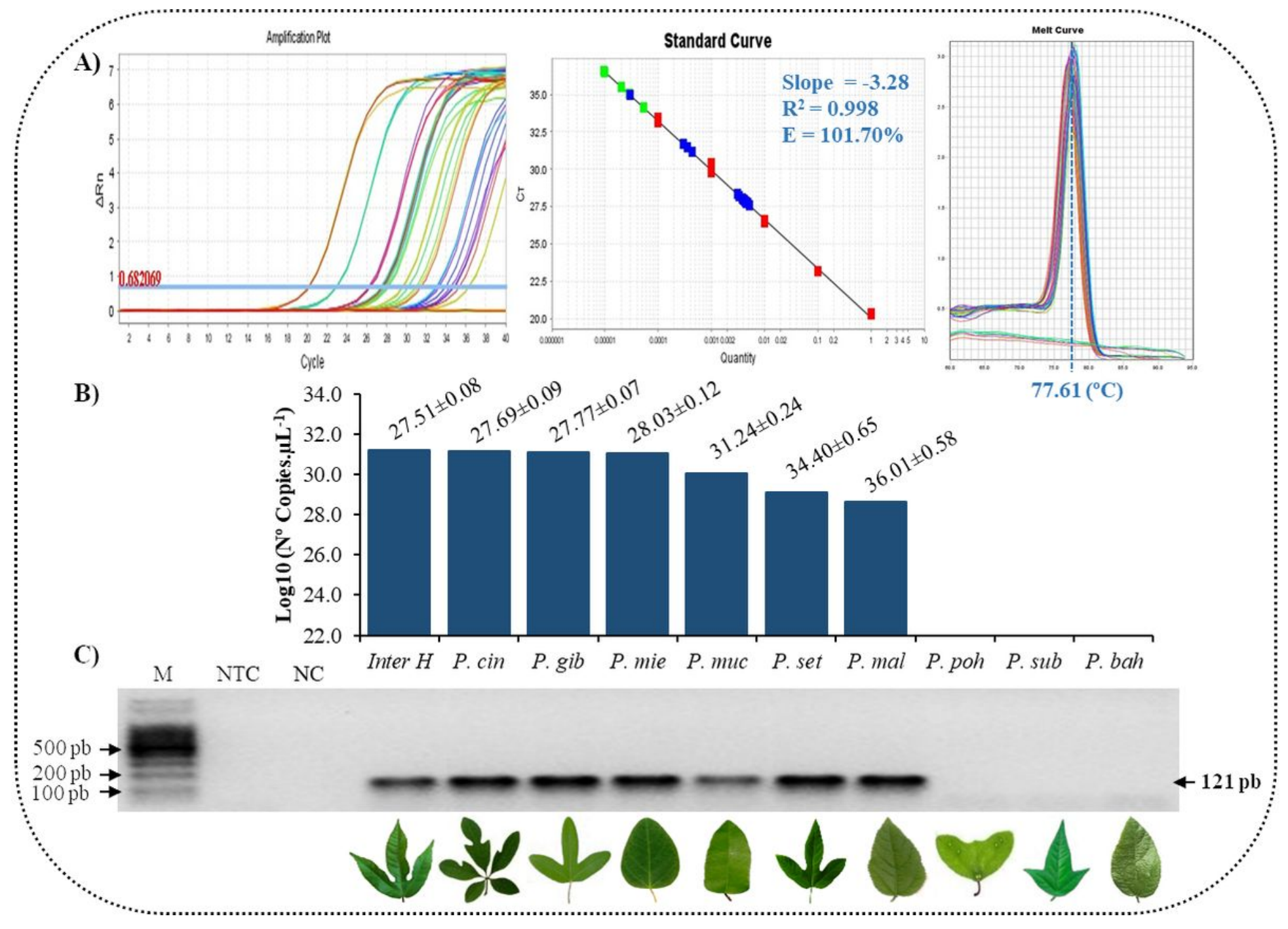

Figure 10

Detection and quantification of CABMV in plants of Passiflora spp. Asymptomatic inoculated from quantitative real-time PCR technique (qPCR). A) Amplification graph of the standard curve and of the samples, standard curve with the quality and precision parameters of the qPCR reaction and dissociation curves (Melting curve) of the amplifications of the CABMV coat protein gene; $B$ ) Copies numbers (copies. $\mu \mathrm{L}-1$ ) of the CABMV virus expressed in Log10 scale in Passiflora spp. asymptomatic inoculated; C) Genic products from part of the genomic region of the CABMV coat protein of $121 \mathrm{pb}$. Agarose $2 \%$. M $=$ Molecular DNA Marker Ladder of 100 pb (LudwigTM). NTC (No Template Control) $=$ without cDNA as mold; $\mathrm{NC}$ (Negative control) = sample of $\mathrm{P}$. edulis not inoculated with CABMV. Inter $\mathrm{H}=$ Interspecific Hybrid (OTH-137); P. cin = P. cincinnata; P. gib = P. gibertii; P. mie = P. miersii; P. muc = P. mucronata; P. set $=$ P. setacea; P. mal = P. malacophylla; P. poh = P. pohlii; P. sub = P. suberosa; P. bah = P. bahiensis. The numbers above the bars represent the mean values of the Cycle threshold $(\mathrm{Ct})$ of the three technical replicates and the standard deviation (SD) of the Ct. 


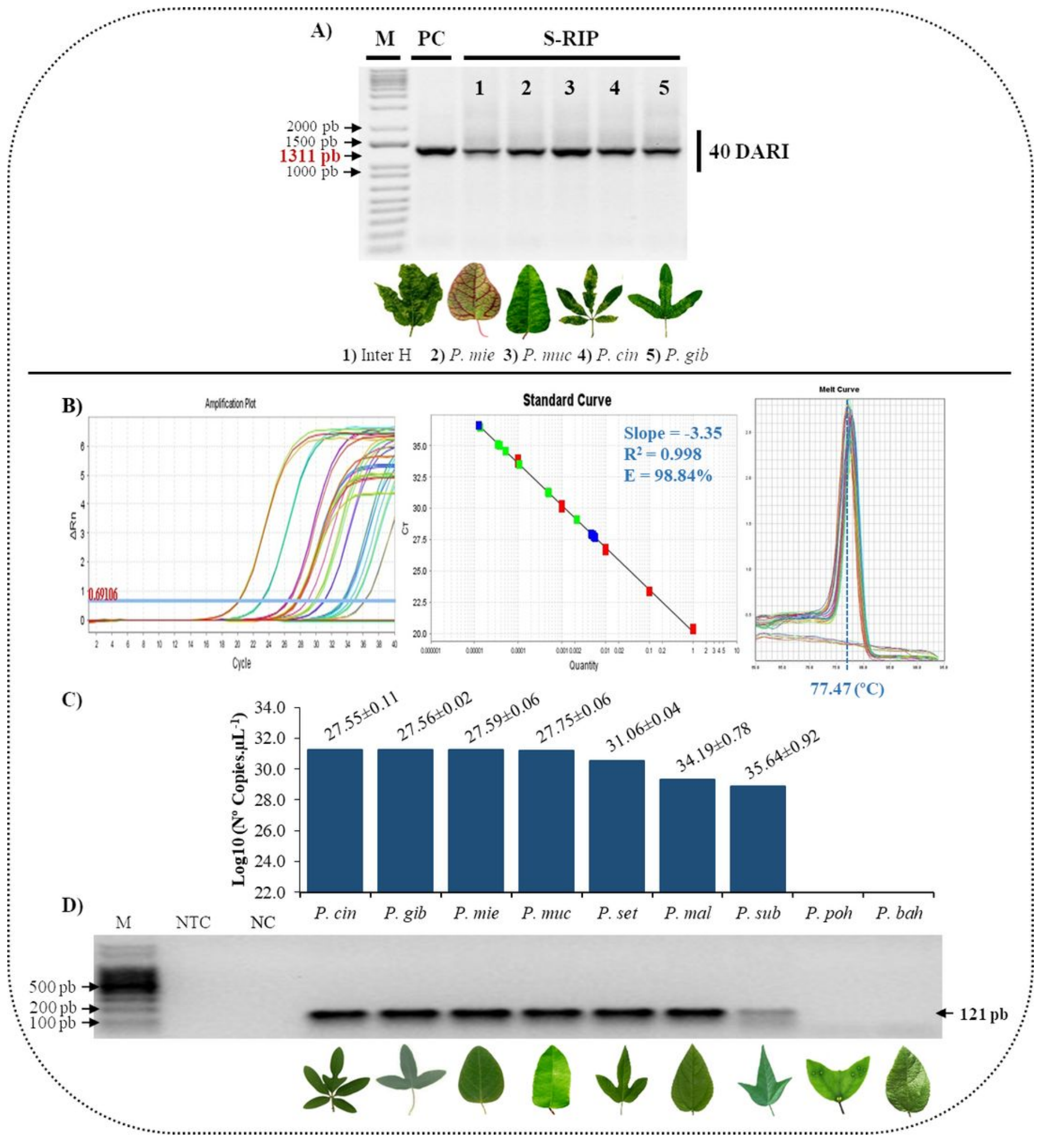

Figure 11

Detection and quantification of CABMV in symptomatic and asymptomatic reinoculated plants by means of qualitative RT-PCR techniques and quantitative real-time PCR (qPCR) at 40 days after reinoculation (DARI). A) Amplification products by RT-PCR of the cylindrical inclusion of CABMV of $1311 \mathrm{pb}$ in symptomatic reinoculated plants - S-RIP. Agarose 1\%. $M=$ Molecular DNA Marker Ladder of $1 \mathrm{~Kb}$ (InvitrogenTM). PC = positive control (Matrix plant with severe CABMV symptoms - cDNA $200 \mathrm{ng} . \mu \mathrm{L}-1$ ); 
B) Amplification of the standard curve and of the samples, standard curve with the quality and precision parameters of the qPCR reaction and dissociation curves (Melting curve) of the amplifications of the CABMV coat protein gene; $C$ ) Copies numbers (copies. $\mu \mathrm{L}-1$ ) of the CABMV virus in the asymptomatic reinoculated Passiflora spp. species; D) Genic products of the genomic region of the CABMV coat protein of $121 \mathrm{pb}$. Agarose 2\%. M = Molecular DNA Marker Ladder of $100 \mathrm{pb}$ (LudwigTM). NTC (No Template Control $)=$ without mold CDNA; NC (Negative Control) $=$ sample of P. edulis not inoculated with CABMV. Inter H. = Interspecific Hybrid (OTH-137); P. mie = P. miersii; P. muc = P. mucronata; P. cin = P. cincinnata; P. gib $=$ P. gibertii; P. set $=$ P. setacea; P. mal = P. malacophylla; P. sub = P. suberosa; $P$. poh = P. pohlii; P. bah $=$ $\mathrm{P}$. bahiensis. The numbers above the bars represent the mean values of the Cycle threshold (Ct) of the three technical replicates and the standard deviation (SD) of the $\mathrm{Ct}$ of each sample.

\section{Supplementary Files}

This is a list of supplementary files associated with this preprint. Click to download.

- Supplementary1.docx 